Review

\title{
An overview of brine management: Emerging desalination technologies, life cycle assessment, and metal recovery methodologies
}

\author{
Adewale S. Bello ${ }^{a}$, Nabil Zouari ${ }^{a}$, Dana A. Da'ana ${ }^{a}$, John N. Hahladakis ${ }^{\mathrm{b}}$, \\ Mohammad A. Al-Ghouti a, * \\ ${ }^{a}$ Department of Biological and Environmental Sciences, College of Arts and Sciences, Qatar University, State of Qatar, Doha, 2713, Qatar \\ ${ }^{\mathrm{b}}$ Waste Management Program, Center for Sustainable Development, College of Arts and Sciences, Qatar University, State of Qatar, Doha, 2713, Qatar
}

\section{A R T I C L E I N F O}

\section{Keywords:}

Revers e osmosis

Disposal

Sustainability

Environmental impacts

Water resources

\begin{abstract}
A B S T R A C T
This study examines which management methods are the most recent and advanced in managing rejected brine generated from desalination plants. It also provides up-to-date information regarding the most adequate technologies that generate a minimum quantity of rejected brine via the use of minimization techniques and analyzes the method of direct disposal that has lately received noticeable improvements. It further discusses the reuse of discarded brine to recover valuable goods and sequestration of carbon dioxide. Sustainability is an important parameter that needs consideration to achieve un interrupted operation of the discarded brine management to achieve the least environmental, social, and economic aftermath. To properly deal with any environmental issues related to brine disposal, different methods are implemented so that, in the end, higher water recovery is achievable from the desalination processes, namely brine minimization and rejection technologies (pressure retarded osmosis, microbial desalination cell technology), membrane-based technologies (vibratory shear enhanced processing, forward osmosis, electrodialysis, electrodialysis reverse, and electrodialysis metathesis, pervaporation method, thermal-based technologies (wind-aided intensified evaporation, brine concentrators, ohmic evaporator, membrane distillation, multistage flash distillation. This review also critically examined the two conventional approaches commonly used in life cycle assessment (LCA), when evaluating the ecotoxic effect of discarded brine. It intends to discuss the currently available methods and propose an improved method for evaluating the toxicity potential of brine on the aquatic ecosystem originated from seawater desalination plants. The Group-by-Group method takes into consideration the demerits of the two methods of the traditional method of LCA or chemical-specific approach as it provides a more holistic coverage for complicated brine to be disposed of. Recently, attention has been focused on recovering valuable metals from the discharged concentrated brine waste. Certainly, attaining marketable products from the discharged concentrated brine would offer an economic benefit and reducing the whole desalination costs. Ion imprinting polymers have potential applications in metal recovery from brine. Find ing selective, more efficient, and less expensive imprinted polymers for extraction/pre-concentration of valuable ions is a vital and challenging task. Lastly, the brine should be seen as a resource and not as a waste to attain sustainability in its management approaches. Hybrid processes would be highly recommend ed to get the absolute transformation of the discarded brine from desalination processes to more valuable constituents.
\end{abstract}

\section{Introduction}

The population increase across the globe has led to an increase in water demand in agriculture, industrial uses, drinking, etc. Consequently, the production of potable water has become a global issue. Many communities have estimated that a growing population and its associated water demand are much greater than conventional (natural) wa ter resources (Mustafa et al., 2020). It was reported that from 1990 up to 2010, approximately 2.3 billion people have access to upgraded drinkable water sources which include adequately secured wells and supplies through pipes (Connor, 2015). The scarcity of water for agriculture and drinking is a pressing issue, especially in the northern

\footnotetext{
* Correspond ing author.

E-mail address: mohamm ad.alghouti@qu.edu.qa (M.A. Al-Ghouti).
} 


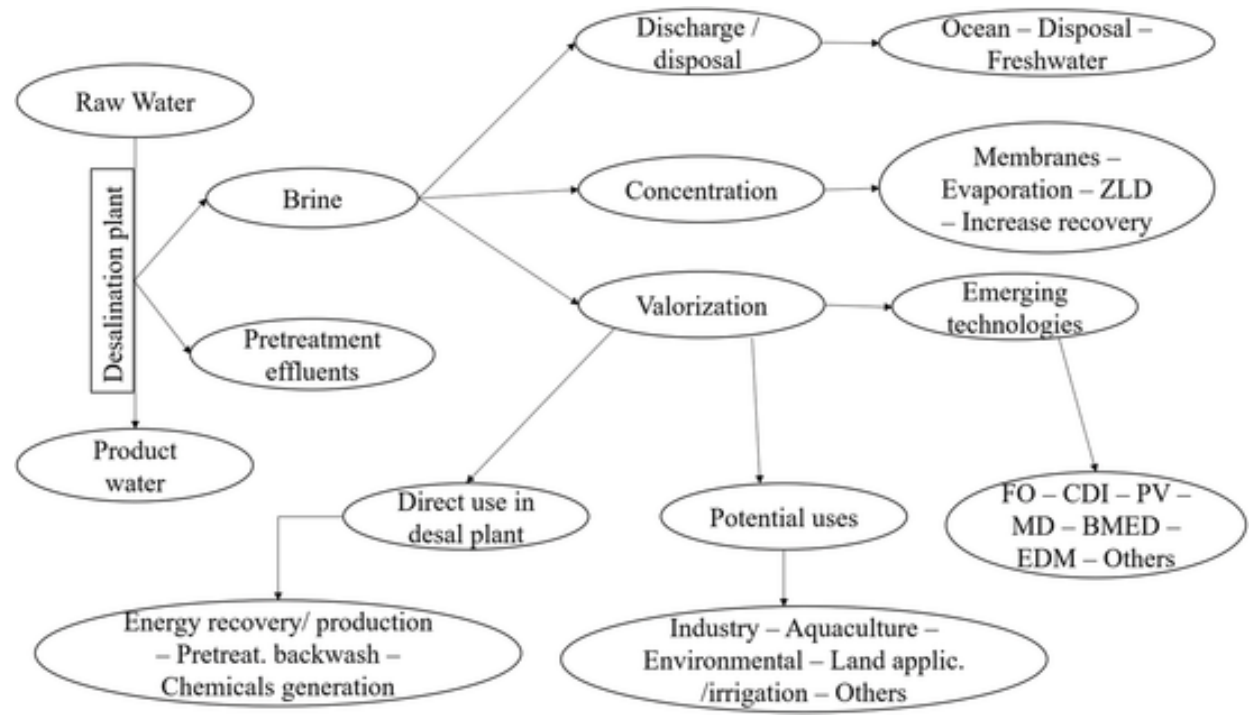

Fig. 1. Generalized brine management strategies/processes, modified from (Gude, 2018).

Table 1

Brines - chemical properties from different sources globally.

\begin{tabular}{|c|c|c|c|c|c|c|c|c|c|}
\hline Country & Australia & USA & China & Italy & Tunisia & Spain & Om an & Qatar & UAE \\
\hline References & Gude (2018) & Martinetti et al. (2009) & $\begin{array}{l}\text { Jiang et al. } \\
\text { (2014) }\end{array}$ & $\begin{array}{l}\text { Ji et al. } \\
\text { (2010) }\end{array}$ & $\begin{array}{l}\text { Hajbi et al. } \\
(2010)\end{array}$ & $\begin{array}{l}\text { Sa dhwani et } \\
\text { al. (2005) }\end{array}$ & $\begin{array}{l}\text { Ahmed et al. } \\
(2001)\end{array}$ & $\begin{array}{l}\text { Dawoud } \\
\text { (2012) }\end{array}$ & $\begin{array}{l}\text { Dawoud } \\
\text { (2012) }\end{array}$ \\
\hline Plant Location & Abrera & California & $\begin{array}{l}\text { Lab scale } \\
\text { Hefei, Anhui }\end{array}$ & Calabri & Skhira & $\begin{array}{l}\text { Ca nary } \\
\text { Islands }\end{array}$ & Esheriah & $\begin{array}{l}\text { Abu- } \\
\text { fintas }\end{array}$ & $\begin{array}{l}\text { Qidfa II } \\
\text { Fujairah }\end{array}$ \\
\hline Plant type & $\begin{array}{l}\text { Electrodialysis } \\
\text { reversal (EDR) }\end{array}$ & $\begin{array}{l}\text { Eastern Municipal Water } \\
\text { District (EMWD) }\end{array}$ & $\begin{array}{l}\text { Revers e } \\
\text { osmosis (RO) }\end{array}$ & BWRO & RO & SWRO & BWRO & NR & BWRO \\
\hline Raw water source & River & Groundwater & Seawater & Seaw ater & $\begin{array}{l}\text { Drilling } \\
\text { water }\end{array}$ & Seaw ater & Groundwater & Seaw ater & Seaw ater \\
\hline Temperature & NR & NR & NR & NR & NR & NR & NR & 40 & 29.1 \\
\hline $\begin{array}{l}\text { Potential of } \\
\text { Hydrogen }\end{array}$ & NR & NR & NR & NR & NR & NR & NR & 8.2 & 7.99 \\
\hline Calcium (mg/L) & 960 & 1032 & 0.306 & 625 & 540 & 814 & 841 & 1350 & 631 \\
\hline Magnesium (mg/L) & 344 & 318 & 6.193 & 2020 & 245 & 2751 & 1900 & 7600 & 2096 \\
\hline Sodium (mg/L) & 1150 & 991 & 159.4 & 15,500 & 2084 & 20,657 & 14,800 & NR & 18,293 \\
\hline Potassium (mg/L) & 422 & NR & 0.4830 & NR & 79 & 814 & 631 & NR & NR \\
\hline Strontium (mg/L) & 103 & NR & NR & NR & NR & NR & 18.3 & NR & NR \\
\hline Barium & 10.9 & NR & NR & NR & NR & NR & NR & NR & NR \\
\hline $\mathrm{pH}$ & 6.9 & 7 & NR & NR & 4 & NR & 6.94 & NR & NR \\
\hline $\begin{array}{l}\text { Bicarbonates } \\
\qquad\left(\mathrm{HCO}_{3}^{-}\right)(\mathrm{mg} / \mathrm{L})\end{array}$ & 885 & 576 & NR & 199 & NR & 452 & 221 & 3900 & 149.5 \\
\hline $\begin{array}{l}\text { Ca rbonate, } \mathrm{CO}_{3}^{2-} \\
\quad(\mathrm{mg} / \mathrm{L})\end{array}$ & 909 & 1.6 & NR & NR & NR & NR & NR & NR & NR \\
\hline Chloride (mg/L) & 3443 & 2823 & NR & 28,800 & 4068 & 37,639 & 24,062 & 29,000 & 31,905 \\
\hline Fluoride (mg/L) & NR & NR & NR & NR & NR & NR & NR & NR & NR \\
\hline Sulfate $(\mathrm{mg} / \mathrm{L})$ & 1344 & 1553 & NR & 3060 & 2160 & 5628 & 6139 & 3900 & 4800 \\
\hline $\begin{array}{l}\text { Total phosphate, } \\
\text { (mg/L) }\end{array}$ & NR & 0.4 & NR & NR & 0.04 & NR & NR & NR & NR \\
\hline Nitrate, (mg/L) & 104 & NR & NR & NR & NR & NR & 5.5 & NR & NR \\
\hline $\begin{array}{l}\text { Free Chlorine Gas } \\
\qquad\left(\mathrm{Cl}_{2}\right), \mathrm{ppm}\end{array}$ & NR & NR & NR & NR & NR & NR & NR & Trace & NR \\
\hline Silica $\mathrm{SiO}_{2}(\mathrm{mg} / \mathrm{L})$ & 4.9 & 116 & NR & NR & 56 & NR & NR & NR & 17.6 \\
\hline $\begin{array}{l}\text { Electrical } \\
\text { conductivity } \\
(\mu \mathrm{S} / \mathrm{cm})\end{array}$ & 13,060 & NR & 1000 & NR & 13,500 & NR & 61,100 & NR & 79.6 \\
\hline Silicon (mg/L) & NR & NR & NR & NR & NR & 9 & NR & NR & NR \\
\hline
\end{tabular}

part of African countries, the Middle East, and a large number of other countries in the Southeastern part of Asia as well as Latin America (Ahuja, 2019; Hardoy et al., 2013; Manzoor et al., 2017). If adequate intervention is not taken, similar issues pertaining to water availability will be spread to several countries within Europe, particularly the member countries of the European Union (EU), as well as of the northem part of the Mediterranean by the year 2020; that will include Greece, Italy, Portugal, and Spain. Considering the Mediterranean alone, the estimation of conservation activities has been greatly affected due to the scarcity of water to the tune of 10 million $\mathrm{m}^{3} /$ day during the year 2020 (Ahmed et al., 2001; Le Dirach et al., 2005).

On the other hand, excessive pressure on freshwater resources leads to an alternative way of water supply; the one through desalination. The construction of desalination plants has been increasing globally, and on a daily basis, to reduce the scarcity of freshwater (Lattemann et al., 2008; Amma and Ashraf, 2020). The Gulf Cooperation Council 


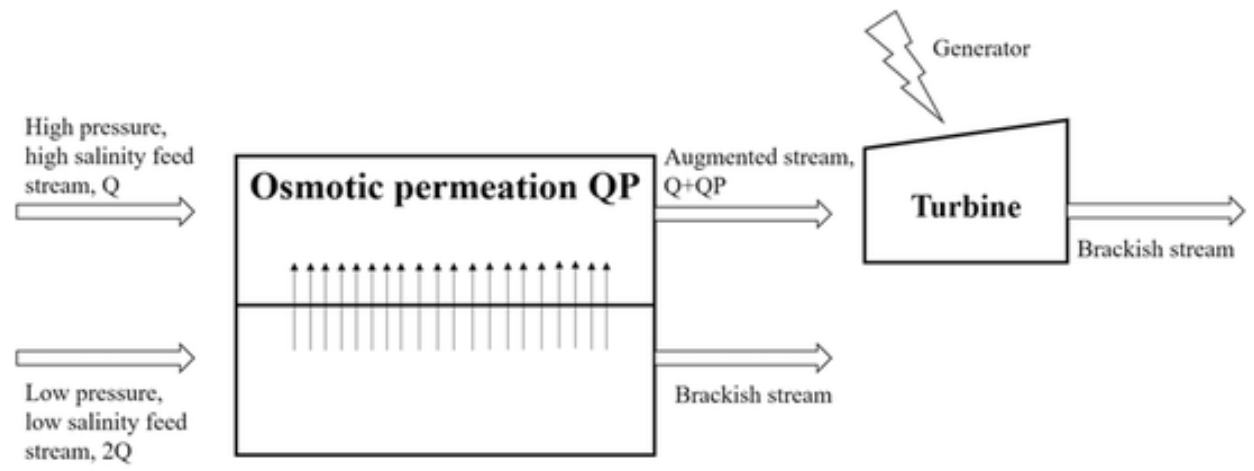

Membrane module

Fig. 2. Schematic drawing illustrating the pressure-retarded osmosis process. Water permeates through a selective membrane from a dilute stream (freshwater) into a pressurized concentrated stream (seawater) and is then expanded through a hydro-turbine (Ramon et al., 2011).

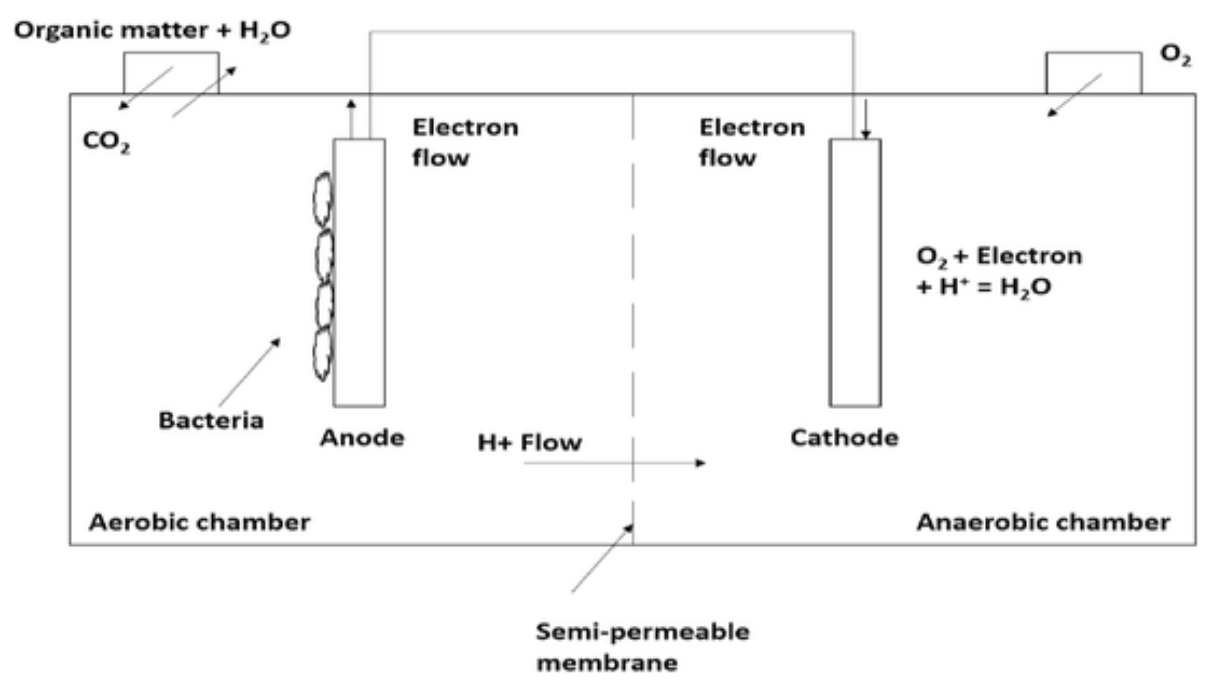

Fig. 3. General scheme of the microbial fuel cell, modified from (Mercer, 2015; Saeed et al., 2015).

(GCC) region is heavily dependent on the construction of desalination plants in large numbers around the Middle East (Fath et al., 2013). Desalination technology will keep growing within the GCC region because these countries are more stressed due to the prevalence of harsh climatic conditions in the region. Hence, agricultural production heavily depends on irrigation and most of the water comes from desalination plants. A good example is the United Arab Emirates (UAE), where the sources of potable water largely depend on desalination, by employing the most influential technology known as Multi-Stage Flash (MSF), while Reverse Osmosis (RO) is next in the hierarchy (Al-Othman et al., 2018). However, although desalination unarguably provides fresh clean water, the reject brine by-product has been known to be a very critical environmental contaminant (Afrasiabi et al., 2011; Al Bazedi et al., 2014; Abdul-Wahab and Al-Weshahi, 2009); that is because there is a lot of residue from pretreated chemicals associated with the brine, also coupled with the high salinity and temperature levels. The reject brine contains several potentially toxic metals (copper, nickel, iron, chromium, zinc, and others), due to pipe corrosion, posing consequential environmental threats (Giwa et al., 2017; Wu et al., 2018).

The reject brine can inflict potential damages to the ecosystem, which may lead to $\mathrm{pH}$ fluctuation, eutrophication, proliferation associated with toxic metals deposited in the aquatic ecosystem, sterilizing qualities of disinfectants capable of causing various problems within the aquatic, as well as underground habitat (Petersen et al., 2018; Xevgenos et al., 2016). Thus, there is a need to apply a more appropriate method to manage brine that will be environmentally benign, putting into account at the same time, all essential parameters involved, such as chemical components of concentrate, reject brine volume, associated cost (capital and operational), geographical region, as well as the disposal area (Giwa et al., 2017; Chung et al., 2017). The clear managerial system in relation to public allowa nce, storage capacity, and transportation, means of evacuating the reject brine to the final destination for treatment, are parameters that should be critically considered (Ahmed et al., 2001; Einav et al., 2003; Xevgenos et al., 2015).

The well-known different strategies adopted to reject brine management include, but are not limited to, brine minimization and direct disposal or reuse. The membrane and thermal-based technologies are associated with a minimization strategy, while direct disposal strategies are methods of disposing the brine directly into the inland offshore. In addition to the aforementioned strategies, managing rejected brine leads to the extraction of minerals and salts for various other purposes and applications (De Buren and Sharbat, 2015).

Ba sed on our knowledge, no paper reviews brine management by taking into consideration the emerging desalination technologies, life cycle assessment (LCA) as well as methodologies for metal recovery. Therefore, the novelty and the main aims of this review article are to examine which management methods are the most recent and advanced in managing rejected brine generated from desalination plants. It provides up-to-date information regarding the most adequate technologies that generate a minimum quantity of rejected brine via the use of minimization techniques. It also analyzes the method of direct disposal that has lately received noticeable improvements. It further dis- 


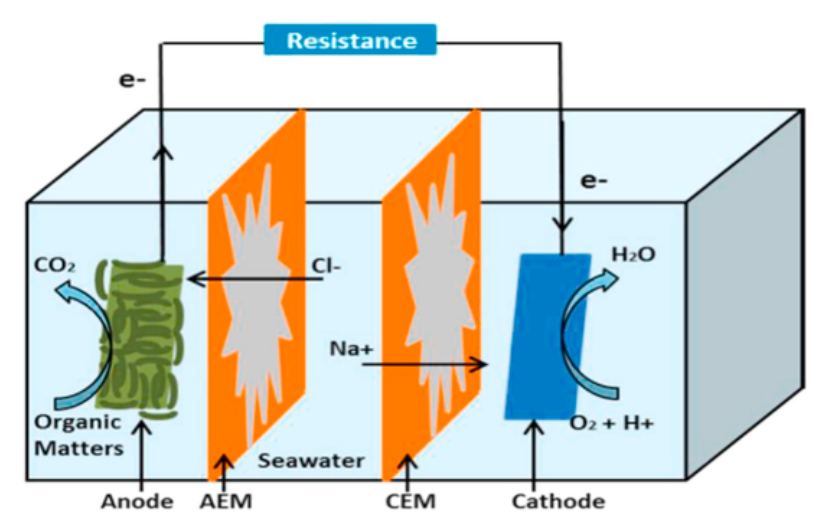

Fig. 4. A microbial desalination cell (Saeed et al., 2015).

cusses the reuse of discarded brine to recover valuable goods and sequestration of carbon dioxide. Sustainability is an important parameter that needs consideration to achieve uninterrupted operation of the discarded brine management to achieve the least environmental, social, and economic aftermath. Due to va rious environmental and cost problems associated with the disposal of brine, several recovery technologies have emerged. A good example is the generation of renewable energy, used within the evaporation ponds from where salt or industrial chemicals are produced (Ahmed et al., 2002). Finally, the review analyzes and evaluates recent and current management systems and minimizing strategies, with a specific focus on emerging technologies.

The paper is divided into the following sections: availability and supply, point source management and processing, exposure and usage, sustainability framework, and best practices by utility companies and users.

\section{Availability and supply}

Brine is the saline solution generated from desalination plants as a by-product with different chemical compositions and concentrations that are mostly determined/regulated by the source of water, quality, and plant recovery (Katal et al., 2020). Brine exhibits similar properties in different parts of the universe, however, it is totally different with regards to toxicity levels or content of potentially hazardous substances i.e. toxic metals $(\mathrm{Hg}, \mathrm{Co}$, and $\mathrm{Ni}$ ), pesticides, and other pollutants that render the disposal of brine, making it a potential environmental threat.

Considering the schematic diagram showed in Fig. 1, the various existing brine management methods are itemized and linked, giving this review a more clarity and better understanding of raising concepts.

The brine characteristic or composition is greatly influenced by the quality of the raw water, as well as plant recovery. In the case of seawater reverse osmosis (SWRO) plants, the range of recovery has been of ten betw een $40 \%$ and $45 \%$. In summary, brine salinity/salt levels will be almost twice when compared with seawater (Gude, 2018). However, the salt concentration in brine tends to be four folds the salinity of brackish wa ter because the average recovery is as much as $75 \%$ (Li et al., 2013). Table 1 presents the chemical characteristics of brine that originated from various plants in different countries. However, some parameters and chemical constituents such as temperature, the potential of hydrogen, strontium, barium, carbonate, and bicarbonate are not reported (NR) in some of the literature used.

\section{Point source management and processing}

Virtually $100 \%$ wa ter recovery is not achievable in nearly all desalination technologies. Hence, desalination plants generate sufficient amounts of brine waste, containing different substances (RodríguezDeLa Nuez et al., 2012). To properly deal with any environmental issues related to brine disposal, different methods are implemented so that, in the end, higher water recovery is achievable from the desalination processes.

The lately developed technologies and processes suggest and critically study the potential of higher water recovery in the course of a brine treatment (Cobban et al., 2011). These processes fall, mainly, into two categories, namely the thermal-based and the membrane-based (pressure and electrical potential driven). Some schemes such as zeroliquid discharge (ZLD) or near-to-ZLD are still under investigation to reduce the volume of rejected brine and equally get back sufficient water at the same time (Panagopoulos et al., 2019; Gorjian et al., 2019). In this case, a substantial amount of pure distillate attaining 95-99\% recovery potential is obtainable from the well-planned waste brine streams. However, the generated residual wa ste can be sent to landfills, but it is not considered an optimal solution. To be able to recover wa ter with high quality and purity, coupled with profitable and economic brine by-products, at a reasonable operational and energy consumption cost, will require a revolution in the desalination industry (Kazner et al., 2014; Martinetti et al., 2009; Burnett, 2011). Ferry et al. (2020) described the performance of commercial thermal evaporator powered combined with external compound parabolic concentrator (XCPC) as a solar energy collector that provides high operating temperatures. This combination provides an alternative to gas-fired evaporators as well as providing an environmentally friendly brine management solution with reduced costs. Results showed that $90 \mathrm{~m}^{2}$ array of XCPC successfully powered a 10 gallon-per-hour commercial thermal evaporator, in which the 10 gallons were evaporated by a solar field of $30 \mathrm{~kW}$ at an outlet temperature of $150{ }^{\circ} \mathrm{C}$ with a total of $80 \%$ reduction in wastewater volume. Furthermore, Dindi et al. (2018) investigated a novel approach for brine treatment where mixed metal oxides derived from $\mathrm{Mg}-\mathrm{Al}$ layered double hydroxide (LDH) were used. Results indicated the feasibility of this process for the treatment of reject brine where approximately $70 \%$ and $20 \%$ reduction of chloride and sodium concentration were obtained, respectively. This reduction ensures safe disposal of the brine as the concentrations are close to that of the seawater. Usually, the Solvay process focuses on the removal of sodium ions, but the proposed process can remove both sodium and chloride ions making it more advantageous over the other methods. Moreover, Desai et al. (2018) used a zinc/ferricyanide hybrid flow battery, which achieves extensive first-pass desalination with a simultaneous supply of $10 \mathrm{Wh} /$ $\mathrm{L}$ electrical energy. Results showed that this technique was able to remove $86 \%(100 \mathrm{~g} / \mathrm{L} \mathrm{NaCl})$ salt from hypersaline brine. The following subsections describe various brine minimization and rejection technologies.

\subsection{Pressure retarded osmosis (PRO)}

Pressure retarded osmosis (PRO) is one of the improved current techniques in use to separate a liquid from a concentrated solution subjected to high pressure so that salinity - gradient produces renewable and emission-free energy as a harvesting energy.

The cleanliness and reliability property of natural salinity gradients is responsible for its importance in harnessing the salinity gradient associated with moving river water characterized with "definite" quantity of seawa ter obtained (Cheng et al., 2018; Gong et al., 2017; Hoover et al., 2011; Ripin et al., 2019). In this system, the mixing of freshwater with brine was enhanced by employing the use of Gibbs free energy to generate power known as salinity - gradient energy or better called osmotic power. The operating system in PRO is relatively easy; facilitated by the chemical potential difference, diffusion of water occurs via a semipermeable membrane of low concentration (high chemical potential) into a high concentration (low chemical potential), excretes pressure in the stream; leading to its pressure and flow rate increase (Loeb et al., 1976; Norman, 1974; Ramon et al., 2011). 


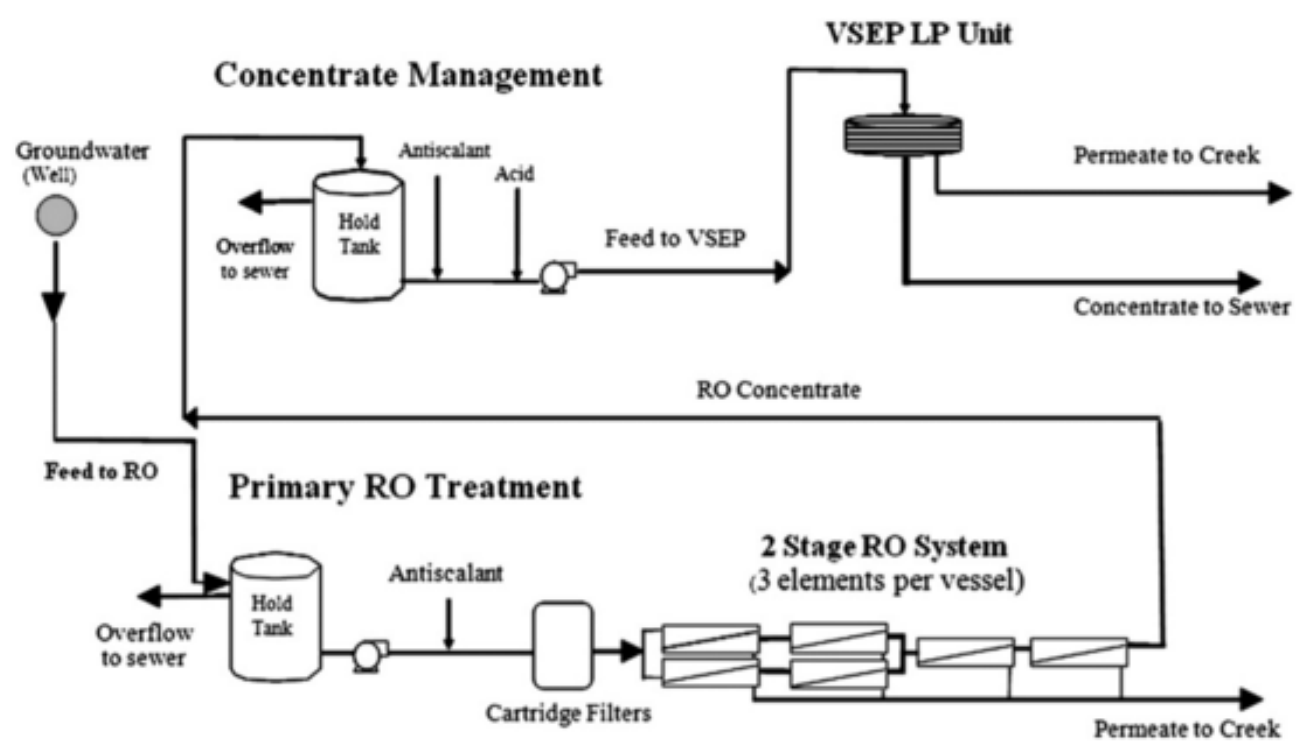

Fig. 5. Schematic illustration of the pilot-scale VSEP treatment system (Subramani et al., 2012).

The simple process is shown in Fig. 2 where the compounded pressurized streamflow via a hydroelectric turbine that responsible for power extraction. The water chemical potential is responsible for the osmosis across the membrane being driven by the driving force that occurs where the temperature of the system is constant (isothermal system), and it can be described as the differentiation between concentrated and dilute solutions in terms of their osmotic pressure. However, this driving force diminishes as a result of the hydraulic pressure applied, the resulted 'pressure-retarded' osmotic water flux is mathematically represented as:

$\mathrm{J}_{\mathrm{W}}=\mathrm{A}(\Delta \pi-\Delta \mathrm{P})$

Where A stands for the membrane water permeability, $\Delta \mathrm{P}$ the hydraulic pressure drop across the membrane, and $\Delta \pi$ the osmotic pressure differential across the membrane.

The PRO existence has been recorded since the 1970s, but gained more recognition lately, mainly via the development of a more reliable and effective membrane. The PRO membrane is characterized by its potential to resist the hydraulic pressure often associated with the inlet stream. The achievable maximum power generated is realized when the pressure applied is almost half the amount of osmotic pressure; this implies that the more the differences in concentration (the largest source of energy), the more the pressure applied to the maximized power output.

\subsection{Microbial desalination cell (MDC) technology}

There is a huge number of desalination technologies in operation nowadays with high efficiency in performance; however, the main limitation with virtually all is their high-energy demand for operation. The best option to overcome this challenge is the adoption of the microbial desalination cell (MDC) technology, with the ability to turn the stored energy in the wastewater to more beneficial and productive energy that could be utilized in desalination as the source of power (Al-Ma mun et al., 2018; Li et al., 2017; Ma vukkandy et al., 2019). The MDC is a derivative of the microbial fuel cell (MFC) technology. The component of MFC is made up of an anode (-ve ion), the cathode (+ve ion), the cation-selective membrane as well as wire externally placed as shown in Fig. 3. The anode and cathode are subjected to aerobic and anaerobic conditions and maintained throughout the process.

The operation of MDCs is often facilitated by utilizing the microorganisms that exist in the wastewater to transform the biochemical en- ergy embedded in organic substances into electricity. The creation of a potential gradient across both anode and cathode terminals can make desalination occur. It shows a distinctive difference to the several types of water desalination methods that need as much as 6-68 kWh of energy to treat $1 \mathrm{~m}^{3}$ of seawater. While MDCs has the advantage of producing more energy to the tune of about $180-231 \%$ when compared with other technologies, in the $\mathrm{H}_{2}$ form according to Wang and Ren 4 in the simple desalination the involves $\mathrm{NaCl}$ solution from $30 \mathrm{~g} / \mathrm{L}$ to $5 \mathrm{~g} / \mathrm{L}$ (Mavukkandy et al., 2019). A normal MDC component is made up of an anode and cathode compartment for the electron exchange or movements, coupled with the desalination chamber in the center built, in such a way that a cation-exchange membrane (CEM) and anionexchange membrane (AEM) overlaps in the two sides of the unit as shown in Fig. 4.

The functions of the two compartments are different, while the anode compartment causes the breakdown of organic and generation of electricity; the central compartment facilitates the elimination of salt from seawater, and finally, the cathode compartment enhances the completion of the electrical loop within the system (Luo et al., 2012; Sa eed et al., 2015). The oxidation of organic matter into carbon dioxide $\left(\mathrm{CO}_{2}\right)$ and releasing hydrogen ions $\left(\mathrm{H}^{+}\right)$into the analyte are enhanced by the bacteria present in the seawater. This chemical process further sees the movement of the electron towards the cathode terminal via an electric circuit external to the system and from this, the oxygen $\left(\mathrm{O}_{2}\right)$ is accepted in the external electron that later underwent reduction to produce water as one of the products. It has been established that this process is capable of salt removal to the tune of over $99 \%$ of salty water coupled with energy production ion excess more than the external required energy needed to power the system (Forrestal et al., 2012; Sa eed et al., 2015).

\subsection{Membrane-based technologies (low-salinity brine)}

\subsubsection{Vibratory shear enhanced processing (VSEP)}

This is an emerging technology that enhances membrane base strategies compared to the conventional membrane-based system (Balasubramanian, 2013; Shi et al., 2011). The treatment of reverse osmosis (RO) takes place in a VSEP unit by utilizing configuration (Balasubramanian, 2013; Shi and Benjamin, 2011). The RO concentrate is used in feeding the system to improve total recovery from the brackish water origin. The principle or mechanism behind this operation is to establish vibratory shear to be able to make oscillation $(50 \mathrm{~Hz})$ within the surface of the membrane so that the shear is ten 


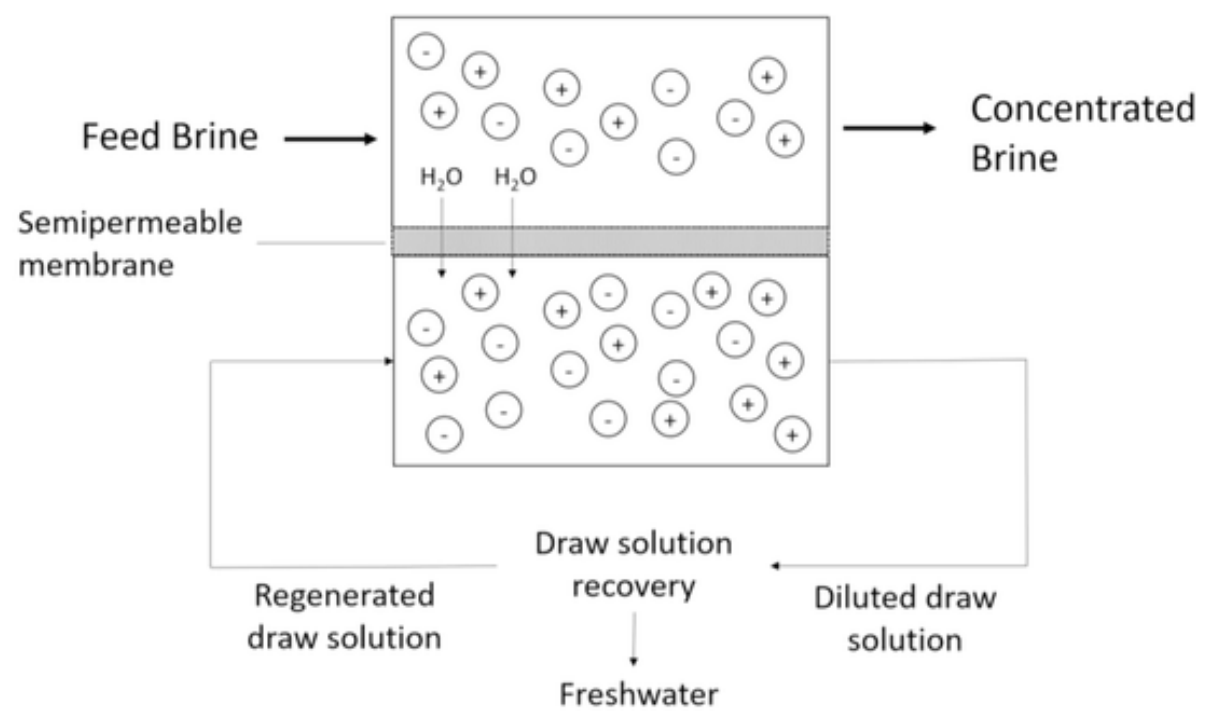

Fig. 6. Schematic illustration of the FO process, modified from (Panagopoulos et al., 2019).

times greater than the normal cross-flow system (Balasubramanian, 2013). Brine concentration reduction is often considered as the available residual. Unlike a normal RO process, VSEP distribution is not affected in any way by the availability of colloids, solid suspension, or salt solubility. Hence, better or higher filtration rate, membrane scaling resistance, and reduction in footprints are a few of the VSEP pros (Subramani et al., 2014). Using VSEP, adequate consideration is needed, in accordance with the energy requirement, to mainta in vibration gear up through torsional spring. Higher fluxes $\left(50-100 \mathrm{~L} / \mathrm{m}^{2} \cdot \mathrm{h}\right)$ and improved total recovery of wa ter fed from $75 \%$ to $93 \%$ have been reported; plus, scaling potential was equally reduced (Subramani and Jacangelo, 2014). Furthermore, Subramani et al. (2012) used VSEP for the treatment of the generated concentrate from a spiral wound RO system during the desalination of brackish groundwa ter desalination. Results showed that the overall feed water recovery of the desalting process was enhanced, and high fluxes were achievable $\left(50-100 \mathrm{~L} / \mathrm{m}^{2}\right.$ $\mathrm{H})$. Moreover, the deposition of colloidal silica wa s restricted to the surface of VSEP membrane. Fig. 5 illustrates the used VSEP treatment system used in this study.

\subsubsection{Forward osmosis}

The forward osmosis (FO) exhibits a major difference to RO due to the associated pressure present in both methods. RO uses applied force as its main force to achieve mass production via the membrane, whereas in the case of $\mathrm{FO}$, the driving force is the osmotic pressure that enhances mass transportation (Chung et al., 2012a, 2012b). FO process is one of the most simple and reliable emerging technologies, that is characterized by low energy consumption and minimum pollution potential (Chung et al., 2012a, 2012b; McGinnis et al., 2008). The osmotic pressure needed is generated from a draw solution, known to be highly concentrated, to transport water from a feed stream with a low concentration of the draw solution that is highly concentrated (Neilly et al., 2009). Fig. 6 illustrates the typical FO process.

Martinetti et al. (2009) studied FO to maximize water recovery in the different water desalination processes. In this study, RO brine streams, which are two in number with an approximate total dissolved solids (TDS) concentration range between $7.5 \mathrm{~g} / \mathrm{L}$ - $17.5 \mathrm{~g} / \mathrm{L}$, were subjected to additional desalination by FO with a draw solution of constant concentration $(50 \mathrm{~g} / \mathrm{L} \mathrm{NaCl})$. With $\mathrm{FO}$, less than $80 \%$ of the water was recovered from the rejected brines, with salt precipitation around membranes. The energy requirements for FO are considerably low compared to several other methods of desalination emerging technologies. McGinnis et al. (2007) established that the proposed FO system by McCutcheon et al. (2006), wa s capable of saving energy to the level of approximately $72 \%$ when compared to the RO and an MSF distillation of $85 \%$. It has been equally established from recent studies that operations at a commercially acceptable rate of flow e.g., $15 \mathrm{~L} / \mathrm{m}^{2}$ to $20 \mathrm{~L} / \mathrm{m}^{2}$ created a threatening issue as regards fouling (Bell et al., 2017; Panagopoulos et al., 2019).

\subsubsection{Electrodialysis (ED), electrodialysis reverse (EDR), and electrodialysis metathesis (EDM)}

These processes are aggravated by electrical potential imbibed or used along membrane-based to reduce the volume of brine, as well as scaling ion removal from it. Electrical potential-driven technologies, in membrane-based methods of brine treatment, have generated many results (Korngold et al., 2009; Oren et al., 2010; Tran et al., 2012). These processes ED, EDR, and EDM are very similar in operation and are considered as the major ones for minimizing the brine volume (Giwa et al., 2017).

These processes permit the movement of anions and cations in the solution through membranes that are not permeable to water; thus, water is contained only in one part. The system is good to handle RO concentrate that is characterized as low salinity brine coupled with low cost. The removed calcium amounted to roughly $70-80 \%$, at a $\mathrm{pH}$ of about 11. Meanwhile, at slightly increased $\mathrm{pH}$ (11.5), the removal efficiency of calcium reached $95 \%$, while removal efficiency in magnesium was in the range of 5\%-25\% (Tran et al., 2012).

\subsubsection{Pervaporation method}

Applying the normal conventional method of the desalting membrane such as RO in brine treatment has been so challenging because of the high concentration level of TDS, as it needed high hydraulic pressures to summon the osmotic pressure associated with inlet solution. However, to solve this problem of high TDS, processes that are nonpressure driven in nature, such as pervaporation (PV) have been used (Drobek et al., 2012). Similar non-pressure-driven processes such as membrane distillation (MD) were developed to counter the challenges emanated from TDS in the feed water as reported (Mansour et al., 2017; Adham et al., 2013; Alkhudhiri et al., 2013; Singh et al., 2012). $\mathrm{PV}$ as an evaporative process is very useful for desalting brines that are characterized by high salinity because it does not require to subdue the osmotic pressure (7 MPa) usually emanated from the inlet solution (Huth et al., 2014; Yacou et al., 2015). According to Lee et al. (2010), it was reported that processes, which are associated with non-pressuredriven factors, exhibit a high level of resistance to the formation of particular types of fouling when compared with pressure-driven processes. 

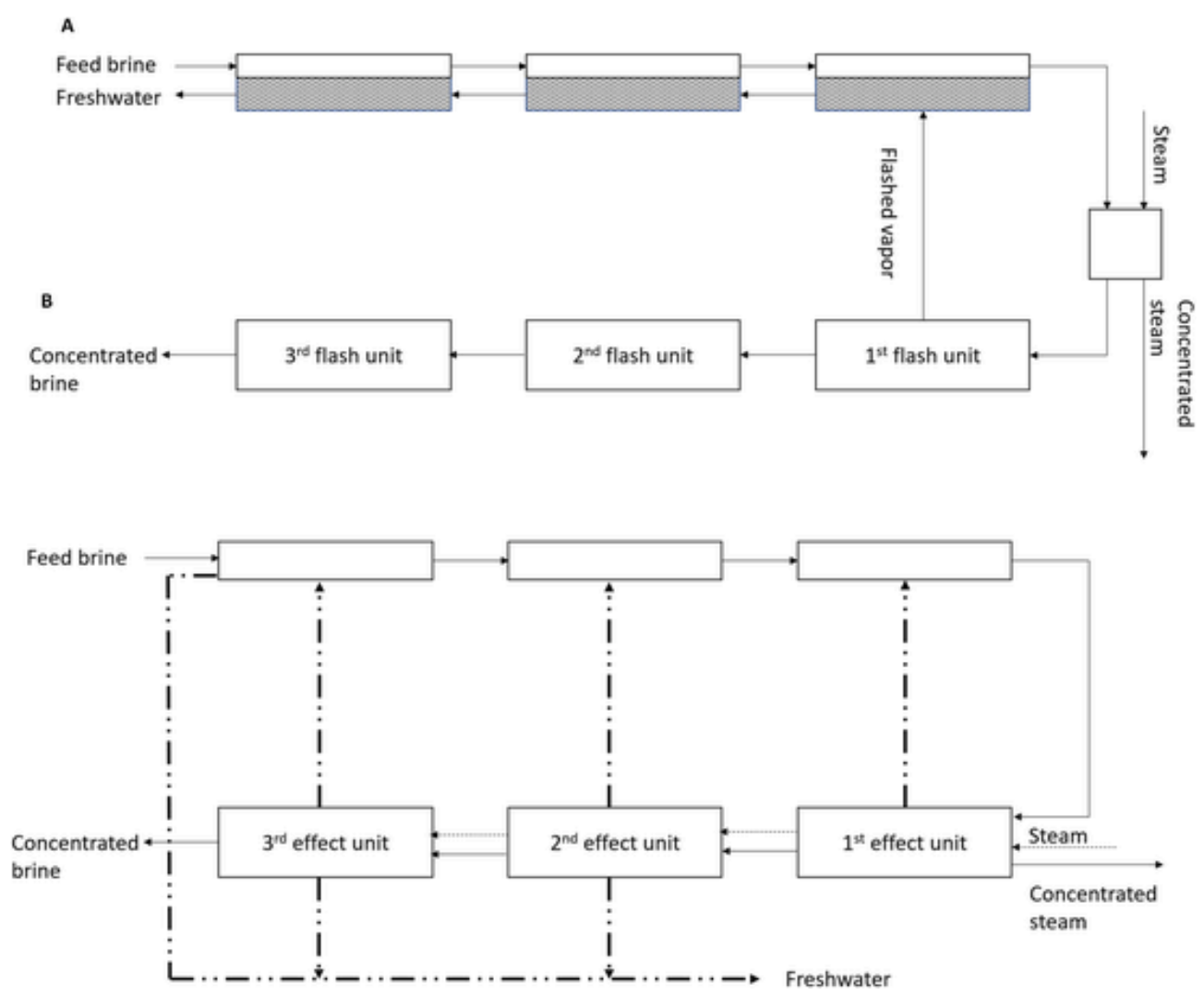

Fig. 7. Schematic representation of the typical: (A) MSF, (B) MED processes, modified from (Panagopoulos et al., 2019).

In the pervaporation desalination applications, it was reported that the efficiencies of salt rejection associated with different kinds of membranes were found to be less than or equal to $99 \%$. It was established that irrespective of the characteristic of the membrane and the operating system, the penetrating ability of the solutes into the structure of the membrane is not preventable, especially if the material is hydrophobic in nature (Quiñones-Bolaños et al., 2005; Zwijnenberg et al., 2005). Besides, it has been established that the salts possess the ability to pass through nonporous forward osmosis membranes (McCutcheon and Elimelech, 2006). The benefit of this approach is that not much importance should be at tached to the hydrophobicity of the membrane, in as much the diffusion of water vapor occurs at pore sizes relatively bigger than those found in the water molecule (Yacou et al., 2015).

\subsection{Thermal-based technologies (high-salinity brine)}

Evaporation is the basic method used in the desalination concentrate treatment, either induced or common natural approach (Giwa et al., 2016). This technique is commonly used in treating high salinity brines. Generally, evaporation ponds serve as a reservoir where the concentrate or reject brine is discharged and water evaporates as the sun heats the solution. This method is considered most suitable for arid regions due to land availability, high sunlight, and coupled with high salinity levels.

\subsubsection{Wind-aided intensified evaporation (WAIV)}

WAIV uses the thermal approach in other to achieve brine volume minimization (Gilron et al., 2003; Katzir et al., 2010; Macedonio et al., 2011; Oren et al., 2010). It uses wind power and allows the evaporation of wetted surfaces that are densely packed. WAIV is preferred to the traditional evaporation ponds, as it requires less land for the operation (Morillo et al., 2014). This technique employs the use of pressurized air, transported via a distribution pipe to the outside layer of the RO concentrate. The evaporation surface is made up of non-woven geotex- tiles that enhance total wind energy efficiency. This system gives the evaporation ratio close to $90 \%$ compared to $78 \%$ of the conventional evaporation ponds. The concentration of TDS has been found to increase by as much as $23 \%$ (Morillo et al., 2014) with WAIV technology. Also, it has the capability of facilitating salt recovery, as a source of raw materials (Morillo et al., 2014). As found in a study, WAIV technology was employed in the RO - ED concentrates as a containment of EDR mode (Oren et al., 2010). For the treatment, it was found that TDS removal was around $70 \%$ and it exhibited a potential, as a method to get back mineral secondary products such as calcium and magnesium salts. Furthermore, RO systems with super concentrate brackish wa ter were equally used. The TDS, in this case, using the WAIV system was greater than $30 \%$ (Gilron et al., 2019).

\subsubsection{Brine concentrators (BC)}

Another promising technology is the brine evaporative cooler concentrator (BECC), designed to minimize the amount of brine through the evaporative cooling technique principle (Cipollina et al., 2011). BECC is characterized by two functions: cooling down recirculating brine and subsequently concentrating it for adequate disposal. According to the study conducted by Cipollina et al., 2011, the stream of brine was, firstly, allowed to cool (via evaporation) as it was mixed with the supplying stream (seawater: chilly) and, secondly, was concentrated with the constituents of the atmosphere (air) when contacted. BECC system is made up of heat conductive surfaces that are kept apart into two streams, which permit cooling part of the system through the recovery of the generated heat, called latent heat, associated with evaporation. Results proved that a range of cooling between $5{ }^{\circ} \mathrm{C}$ and $100{ }^{\circ} \mathrm{C}$ is achievable when the relative humidity was found to be in the range of $40 \%$ and $70 \%$, coupled with wind movement of slightly $2 \mathrm{~m} / \mathrm{s}$ (Lozier et al., 2007). Additionally, some brine concentrators comprise a visual tube that functions as a pathway through, which the concentrate flow when fed (Cipollina et al., 2011). Evaporation of the concentrate took place inside the tube. Latent heat was generated from vapor- 


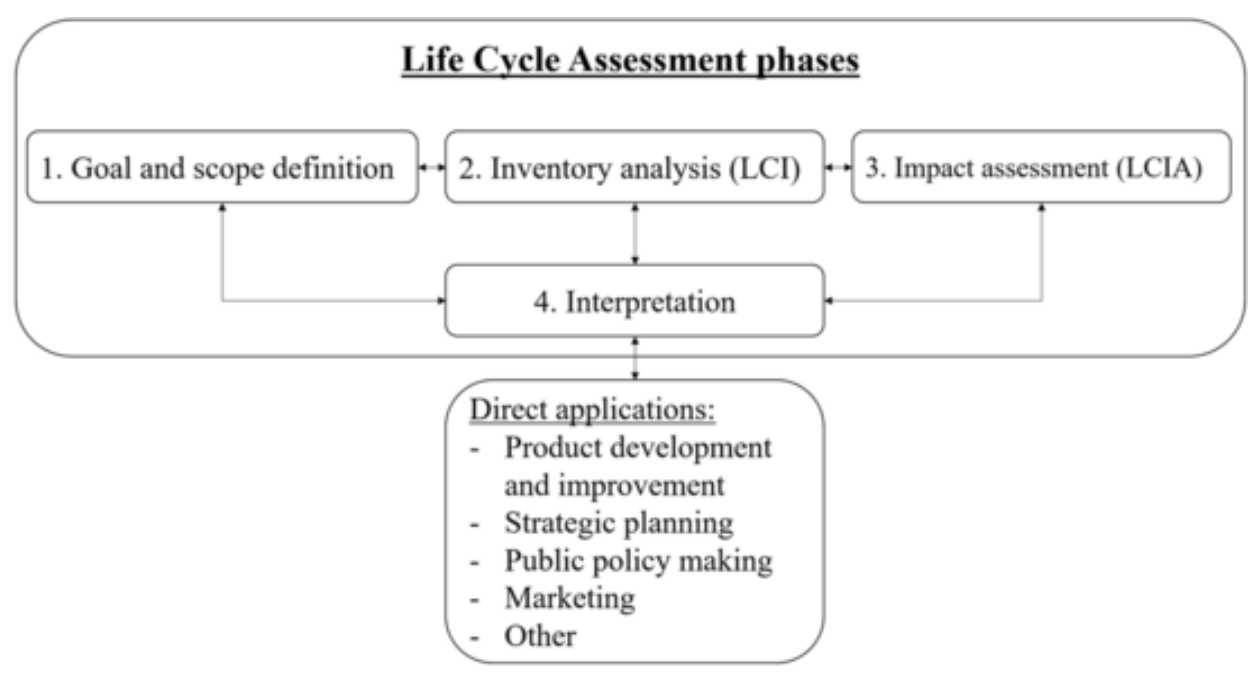

Fig. 8. Phases and applications of an LCA (Rebitzer et al., 2004).

ization when the vapor was condensed on the surface of the tube. Highly pure distilled water was produced from this process, which subsequently led to the reduction of the final brine volume. The associated limiting factors in this process include sulfate and chloride concentration, the brine elevated boiling point, and the sodium salt solubility (Lozier et al., 2007). Almost 95\%-99\% overall recovery is achievable by employing this system.

\subsubsection{Ohmic evaporator $(O E)$}

Similarly, already mentioned, thermal-related emerging technology is also used for brine volume minimization. This technique uses mainly an alternating electric current that operates roughly at $60 \mathrm{~Hz}$ frequency, with an electrical field capacity of $24 \mathrm{~V} / \mathrm{cm}-28 \mathrm{~V} / \mathrm{cm}$ (Assiry, 2011). The technique can only be used to evaporate brine concentrate when its value is greater than $800,000 \mathrm{ppm}$. It has been established that an excellent recovery rate at a range of $81 \%-93.5 \%$ was recorded, at the efficiency performance level of $\mathrm{OE}$ within the electric field capacity of $56 \mathrm{~V} / \mathrm{cm}$ (Assiry, 2011). This technique has not been scientifically investigated enough, taking also into account the high cost of establishing a respective brine treatment unit on a commercial scale (Assiry, 2011; Sakr et al., 2014).

\subsubsection{Membrane distillation (MD)}

The emerging technology approach employed in this case is the membrane distillation that combines the properties of both a membrane and thermal-based technology. Several studies have been conducted to examine the prospects of MD as a technique for treating concentrated brine. The MD combines the membrane, as well as the thermal advancement properties (Ashoor et al., 2016). It is a better substitute for dewatering or draining an aqueous solution of higher concentration. From a simple comparison between them, unlike membrane separation method where the hydraulic pressure differs, electrical potential slope or concentration slope generates the moving force; the moving force associated with MD is known to be the vapor pressure gradient (VPG), obtained from the difference in temperature across the entire membrane (Camacho et al., 2013; Kazner et al., 2014). By maintaining temperature differences of low range $10{ }^{\circ} \mathrm{C}-200^{\circ} \mathrm{C}$ betw een the region of hot and cold stream, the permeate water is likely to be produced. The process of MD is influenced solely by vapor-liquid equilibrium that facilitates the diffusion of volatile constituents over a membrane with microporous and hydrophobicity properties. The existing various MD configurations include vacuum, air gap, sweeping gas, as well as direct contact MD. The direct contact membrane distillation (DCMD) technology is known for its reliability coupled with its easy configuration that can be employed in the process of desalination.
DCMD has one of the sides of the membrane permeable to the hot brine, as well as for the vapor to flow across the holes of the membrane with hydrophobic properties. Due to condensation, the vapor is recovered in a colder form, as distillate, within the second position on the membrane. The concentrated or residual stage was found to contain more of the dissolved salts, as well as other chemicals stuck to the side of the hydrophobic membrane. The benefits of the MD include but are not limited to its driving force, which vapor pressure does not possess under high concentrations of salt, the organic fouling and biofouling are low. Unrestricted potential to merge with various sources of heat, which include geothermal, solar thermal, or wasted heat from machines e.g. heat exchangers, diesel and electrical generators, low operational cost, and capital requirement. The main disadvantage of MD is that permeate flux obtained is low in virtually all cases (Adham et al., 2013; Dow et al., 2008).

\subsubsection{Multi-stage flash distillation and multi effect-distillation}

The most prominent thermal-based technologies in use for brine treatment are multi-stage flash distillation (MSF) as well as multieffect distillation (MED), which are shown in Fig. 7 (Panagopoulos et al., 2019). MSF is the most used technology considering all the available thermal desalination, it amounts to roughly 64\% (Shatat et al., 2014). The emergence of these technologies traces back to the brackish and seawater desalination and they are very effective when the materials are upgraded before the actual treatment of the brine (Mabrouk et al., 2015). The simple mechanism in MSF requires the preheating of inlet brine by making use of condensing vapor, which is often generated from the flash units of the system until it at tains the highest temperature (approx. $110{ }^{\circ} \mathrm{C}-120^{\circ} \mathrm{C}$ ) fa cilitated through an external source of energy. The heated inlet brine moves from the bottom vapor pressure of flash units that caused the parts of the inlet brine solution to evaporate and subsequently condensed in the heat exchangers. There is a difference between the two solutions while the condensed water vapor is known to be the freshwater the other liquid is the concentrated brine that emanates from the flash unit (Khoshrou et al., 2017). This technology shares some similarities, however, they differ in a number of ways, particularly in the heat generated and the highest temperature attained is between 70 and $80^{\circ} \mathrm{C}$ (Elsayed et al., 2018). Despite the effectiveness of this technology, they still have their shortcomings in terms of the high cost of construction because of the special materials needed which are resistant to corrosion (Boillot et al., 2014). The energy requirement by these technologies is high, ranging from $12.5 \mathrm{kWh} / \mathrm{m}^{3}$ to $24 \mathrm{kWh} / \mathrm{m}^{3}$ for MSF and $7.7 \mathrm{kWh} / \mathrm{m}^{3}$ to $21 \mathrm{kWh} / \mathrm{m}^{3}$ for MED. 


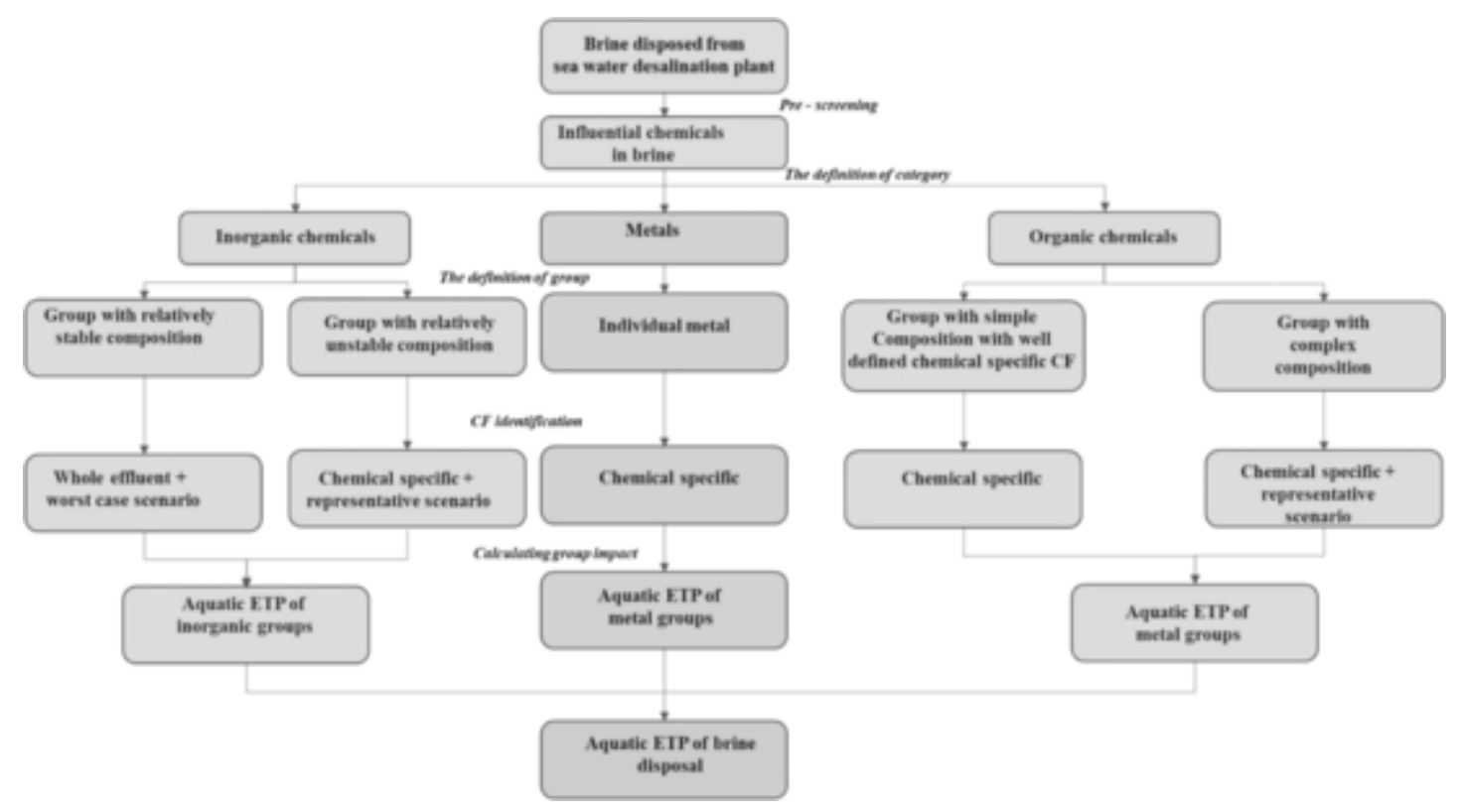

Fig. 9. The process flow of the group-by-group method, modified from (Zhou et al., 2013).

\section{Sustainability framework}

\subsection{Life cycle assessment and life cycle impact assessment (LCIA)}

According to Brancoli and Bolton (2019), LCA is a comprehensive technique that is normally used for the assessment of the associated environmental impacts with the product's life during all the stages including extraction, processing, manufacturing, distribution, and utilization of the materials. This analysis is commonly used to report the consumption of potential environmental loads and resources through the service supply chain of a certain product. The LCA is normally used for supporting the policies and decisions throughout the production supply chain for sustainable development. On the other hand, LCIA determines the potential impact of the obtained data from life cycle inventory by using the impact categories, category indicators, model characterization, equivalency factors, and weighing values. The primary procedure of LCIA have consists of categorizing, classifying, characterizing, normalizing, grouping and integrating environmental impact (Kayo et al., 2014).

\subsection{Phases and applications of an LCA}

The LCA establishment serves as a valuable means of analyzing the impacts on the environment that results due to the freshwater generated from the desalination system because it takes into consideration all the potential environmental problems (Caro, 2019). The LCA comprises of four main phases, namely goal and scope definition, inventory analysis, impact assessment, and interpretation as shown in Fig. 8 (Kylili et al., 2018; Larsen, 2018). However, most of the applications of LCA in the desalination system are in relation to energy demand and water supply, additionally, to evaluate the potential effects of desalination system, and the contribution of concentrate disposal into the water ecosystem (Muñoz et al., 2010; Raluy et al., 2005; Zhou et al., 2013). This can lead to proffering solutions to alleviate the environmental challenges using various means, including effective pretreatment of feed water (Beery et al., 2010) and using cleaner sources of energy such as natural gas (Zhou et al., 2011) and renewable energy sources that include wind and solar (Pehnt, 2006; Raluy et al., 2005).

Besides the energy demands of the desalination process, understanding the eco-toxic potential of brine disposed after desalination has been of great concern. It has been suggested that high salinity, which is caused by the brine disposed, may lead to growth reduction or even death of the flora and fauna where brine is being disposed of. It was also discovered that brine from desalination plants has the ability to impair biological communities by causing toxic chemical accumulation in aquatic organisms such as mussels and algae (Elsaid et al., 2020).

A case study wa s conducted in Southern California, employing a hybrid LCA tool for comparison of three different types of water supply and the imported water case (Stokes et al., 2009). The outcome indicated that the environmental load of the current water importation case is 1.5-2.4 times less than that of alternative methods of desalination, which include brackish groundwater desalination and seawa ter desalination, coupled with recycling water case. Similarly, in other research conducted in Arizona, several factors like seawa ter desalination, reclamation of water, and water importation were compared, and seawater desalination was found to have the highest impact (Lyons et al., 2009). Also, LCA wa semployed to bring out the relationship that exists between environmental loads pertaining to groundwater treatment, RO, thermal desalination, nanofiltration, and ultrafiltration respectively (Vince et al., 2008). Additionally, another study was conducted in Amsterdam for future capacity increase, LCA was used to evaluate and analyze the comparison between two different alternative RO desalination cases (Mohapatra et al., 2002). However, the aquatic ecotoxic potential (ETP) in relation to brine production from desalinationbased LCA researches/studies is scanty. An improved methodology to assess ETP was developed by Zhou et al. (2013).

Furthermore, LCA was mostly applied in analyzing the energy demand in the desalination process and only a few works were done by using LCA for measuring the toxicity potential of brine on the aquatic ecosystem. Meneses et al. (2010) studied the final disposal of brine alternatives using LCA. Nevertheless, they did not take into consideration the impact of salinity because the current method employed could not render the ionic salts into aquatic eco-toxic impact (Meneses et al., 2010). Another work (Vince et al., 2009) considered the potential of the liquid discharge, but this was specifically for a site with inadequate reference value compared to other research works. There are two main reasons that hinder the current LCA with respect to brine disposal. Firstly, much data is required, which is usually intensive, as it requires many efforts to do a comprehensive analysis and an on-site ecotoxicology test. This analysis is quite complex since there is usually a high variation of brine composition. Secondly, there is a misunderstanding of using the existing LCIA methods as a widely accepted standard procedure 


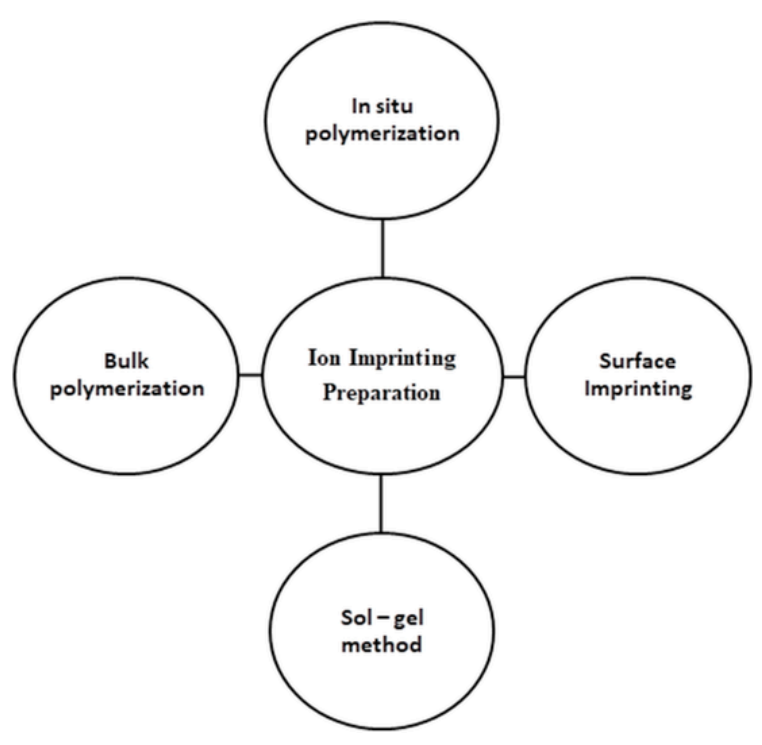

Fig. 10. Schematic diagram of the best method of preparation ion imprinting, modified from Boysen, 2018.

without bearing in mind the reliability and suitability of those methods (Zhou et al., 2013). This part intends to discuss the currently available methods and propose an improved method for evaluating the toxicity potential of brine on the aquatic ecosystem originated from seawater desalination plants.

\subsection{Methods for life cycle assessment (LCA)}

The standard equation considered when calculating the aquatic ETP of brine disposal is as follows:

Aquatic ETP of brine disposal

$=\sum_{\mathrm{i}} \mathrm{m}(\mathrm{i}) \times \mathrm{CF}^{\text {aquatic ETP }}(\mathrm{i})$

The definition of the terms is as follows: $m(i)$ stands for the mass of $1 \mathrm{~m}^{3}$ of a brine sample to be disposed of, and $\mathrm{CF}^{\text {aquatic ETP }}$ (i) denotes the characterization factor (CF) of the aquatic ETP for i. The LCIA methods in question will depend on modifications of equation (1)

\subsubsection{The traditional or chemical method}

The traditional method of LCA is also known as the chemicalspecific approach. This method calculates the average or mean effluent effects as the summation of the effects generated by the entire chemicals within the effluent based on the aquatic (ETP) of each elementary chemical (Vince et al., 2009). The USEtox (Henderson et al., 2011; Rahman et al., 2018) which was developed by the Society for Environmental Toxicology and Chemistry (SETAC) in conjunction with the United Nations Environment Program (UNEP) encompasses the chemical fate, exposure, and effect and is expressed according to equation (2)

$\mathrm{CF}^{\text {aquatic ETP }}(\mathrm{i})=\mathrm{FF}_{\mathrm{i}} \times \mathrm{XF}_{\mathrm{i}} \times \mathrm{EF}_{\mathrm{i}}$

$\mathrm{CF}^{\text {aquatic ETP }}$ (i) is the aquatic eco-toxic characterization factor which denotes the aquatic ecotoxicological influence of chemical individual I. Herein, the impact is enumerated as the potentially affected fraction (PAF) of species [PAF.m ${ }^{3}$. day $/ \mathrm{kg}$ ]. $\mathrm{FF}_{\mathrm{i}}$ is the fate factor is calculated as the persistence time of the chemical $\mathrm{i}$ staying in the aqueous phase [day], $\mathrm{XF}_{\mathrm{i}}$ the exposure factor, which shows the bioavailability of the chemical $i$ to the aquatic organisms, and $\mathrm{EF}_{\mathrm{i}}$ the effect factor, which denotes the ability of a chemical $i$ to cause toxic effects to the exposed aquatic ecosystems [PAF. $\mathrm{m}^{3} / \mathrm{kg}$ ].
The chemical-specific approach is an analytical method appropriate for evaluating effluents comprising of contaminants, which themselves have well-defined ecotoxicological properties. Nevertheless, it has several draw backs. Firstly, it is a method that involves many chemicals, including by-products, most of which are present at a low level of concentration. Secondly, it is not cost-effective with respect to time and other resources due to the analysis of the ecotoxicological properties of all the numerous compounds present. Finally, this method is limited by what is only available in the USEtox model.

\subsubsection{The group-by-group method}

This method takes into consideration the demerits of the two previous methods that are the traditional or chemical, and completely effluent methods discussed earlier. That is to adequately evaluate the complex mixture of effluents (i.e. effluents with unknown chemical mixtures) from brine disposal and take into consideration the instability of the composition of the brine. This method merges the advantages of both the chemical-specific (traditional) and the whole - effluent method. This is achieved by calculating the mean aquatic ETP impact as the summation of the impacts generated by the recognized groups of significant chemicals, hence its name group-by-group method. This method classifies the chemicals from the brine disposal (Zhou et al., 2013). A process flow is illustrated in Fig. 9 showing the stag es from the brine disposal from desalinated plants down to the mean aquatic ETP calculated from the three main groups-metals, inorganic and organic chemicals. In this method, equation (1) can be modified as:

Aquatic ETP of brine disposal

$=\sum_{\mathrm{j}} \mathrm{m}($ group $\mathrm{j}) \times \mathrm{CF}^{\text {aquatic ETP }}($ group $\mathrm{j})$

where (group j) is the mass of the recognized group $\mathrm{j}$, $\mathrm{CF}^{\text {aquatic ETP }}$ (group $\mathrm{j}$ ) denotes the characterization factor (CF) of the aquatic ETP for group $\mathrm{j}$.

It is important to note that the pre-screening step that is to identify the recognized chemicals is based on two principles. Firstly, chemicals with higher concentrations that are greater than the regulated level (provided it is existing) or with higher concentrations than the other chemicals in the brine from the desalination plant to be disposed of if no regulation is available. Secondly, chemicals with characterization factors ( $\mathrm{CFs}$ ) much greater than other chemicals in the brine from the desalination plant. That is the first principle has to do with regulations while the latter has to do with CFs. However, the second principle is applied to evade the error due to truncation instiga ted by the postulations that would be made in the first principle. This implies that both chemicals, that is, those found in large quantities in brine disposal (e.g. copper) and those that may occur in small amounts (e.g. nickel) but characterized with high impact CF should be recognized simultaneously.

This method takes the merits of the traditional or chemical and completely effluent method, as discussed earlier. The advantages of the group-by-group method include the need for fewer data to guesstimate the related impact without compromising significantly on the dependability as compared to the specific chemical method. As depicted in Fig. 9, pre-screening is employed to classify and recognize the chemicals that serve as major contributors hinge on their concentration and CF into three groups (organic, inorganic, and metals). The aquatic ETP of each group may then be calculated using either the traditional, chemical-specific-method or the whole-effluent method depending on the group characteristics and CFs available. As for the chemicals that are quite difficult in groups, alternative chemicals that have similar activity to them can serve as their representatives and be employed during the pre-screening, as this will help reduce the data needed. The second advantage of this method is that it provides a more holistic coverage for complicated brine to be disposed of. This method considers the impact of inorga nic chemicals, aside from organic and metals, which are quite challenging in the LCIA. 
Table 2

Metal recovery from brine by different technologies.

\begin{tabular}{|c|c|c|c|c|}
\hline $\begin{array}{l}\text { Recovered } \\
\text { metal }\end{array}$ & Technology & Efficiency & Econom ic feasibility \& environmental impact & References \\
\hline $\begin{array}{l}\text { Rubidium } \\
\left(\mathrm{Rb}^{+}\right)\end{array}$ & $\begin{array}{l}\text { Integrated MD-SWRO with an adsorbent of } \\
\text { potassium copper hexacyanoferrate in MD feed } \\
\text { tank }\end{array}$ & $96.6 \%$ removal & $\begin{array}{l}\text { The high cost of } \mathrm{Rb}^{+} \text {in the market can compensate } \\
\text { for the process cost. } \\
\text { Reduce environmental impacts by brine volume } \\
\text { reduction. }\end{array}$ & $\begin{array}{l}\text { Naidu et al. } \\
\text { (2017) }\end{array}$ \\
\hline $\begin{array}{l}\text { Rubidium } \\
\left(\mathrm{Rb}^{+}\right)\end{array}$ & $\begin{array}{l}\text { Cation exchange mechanis } \mathrm{m} \text { where ionic liquid } \\
\mathrm{C}_{2} \mathrm{mi}_{\mathrm{mNF}} \text { as a solvent to extract } \mathrm{Rb}^{+} \text {by bis( } 2 \text { - } \\
\text { propyloxy)calix [4] crown- } 6\end{array}$ & $\begin{array}{l}\text { Around } 100 \% \text { at } \\
\text { optimum conditions }\end{array}$ & & $\begin{array}{l}\text { Luo et al. } \\
\text { (2019) }\end{array}$ \\
\hline $\begin{array}{l}\text { Uranium } \\
\text { (U) }\end{array}$ & Adso rption by amidoxime adsorbents & $\begin{array}{l}3.95 \mathrm{mg} / \mathrm{g} \text { were } \\
\text { adsorbed. }\end{array}$ & $\begin{array}{l}\text { High economic value. } \\
\text { Understanding the economic feasibility requires more } \\
\text { analysis. }\end{array}$ & $\begin{array}{l}\text { Wiechert et } \\
\text { al. (2018) }\end{array}$ \\
\hline $\begin{array}{l}\text { Lithium } \\
\qquad\left(\mathrm{Li}^{+}\right)\end{array}$ & Ion-exchange & $>95 \%$ & - & $\begin{array}{l}\text { Arroyo et al. } \\
\text { (2019) }\end{array}$ \\
\hline $\begin{array}{l}\text { Lithium } \\
\qquad\left(\mathrm{Li}^{+}\right)\end{array}$ & $\begin{array}{l}\text { Electrodialysis with monovalent selective ion } \\
\text { exchange membranes }\end{array}$ & & $\begin{array}{l}\text { Using brine to extract } \mathrm{Li}^{+} \text {is more environmentally } \\
\text { friendly compared to the traditional recovery } \\
\text { methods. }\end{array}$ & $\begin{array}{l}\text { Guo et al. } \\
(2018)\end{array}$ \\
\hline $\begin{array}{l}\text { Li thium } \\
\qquad\left(\mathrm{Li}^{+}\right)\end{array}$ & $\begin{array}{l}\text { Electrochemical approach by using selective } \\
\text { lithia tion desalination battery }\left(\mathrm{rGO} / \mathrm{LiNi}_{0.6} \mathrm{Mn}_{0.2} \mathrm{O}_{2}\right)\end{array}$ & $93 \%$ & $\begin{array}{l}\text { It consumes only } 1.4 \mathrm{Wh} / \mathrm{mol} \mathrm{Li}^{+} \text {indicating that it is } \\
\text { a promising electrochemical lithium extraction } \\
\text { approach }\end{array}$ & $\begin{array}{l}\text { Zhao et al. } \\
(2020)\end{array}$ \\
\hline $\begin{array}{r}\text { Cesi um } \\
\left(\mathrm{Cs}^{+}\right)\end{array}$ & $\begin{array}{l}\text { Adsorption with modified potassium cobalt } \\
\text { hexa cyan of erra te }\end{array}$ & $97.33 \%$ & $\begin{array}{l}\text { Capital and operational costs are less than other used } \\
\text { processes. It is profitable only in the case of high- } \\
\text { value minerals extraction. }\end{array}$ & $\begin{array}{l}\text { Yang et al. } \\
\text { (2018) }\end{array}$ \\
\hline $\begin{array}{l}\text { Magnesium } \\
\text { oxide } \\
(\mathrm{MgO})\end{array}$ & Calcination of $\mathrm{Mg}(\mathrm{OH})_{2}$ by $\mathrm{NH}_{4} \mathrm{OH}$ and $\mathrm{NaOH}$ & - & $\begin{array}{l}\text { Higher energy demand than producing } \mathrm{MgO} \text { by dry- } \\
\text { ro ute methods. Further optimi zation is required. }\end{array}$ & $\begin{array}{l}\text { Dong et al. } \\
(2018)\end{array}$ \\
\hline $\begin{array}{l}\text { Nickel \& } \\
\text { vanadium } \\
(\mathrm{Ni} \& \mathrm{~V})\end{array}$ & Ion-exchange system & $98 \%$ & - & $\begin{array}{l}\text { Al-Jaser \& } \\
\text { Ha moda } \\
(2019)\end{array}$ \\
\hline $\begin{array}{l}\text { Magnesium } \\
\left(\mathrm{Mg}^{2+}\right)\end{array}$ & $\begin{array}{l}\text { Extraction with an organic system containing ionic } \\
\text { liquid (by di-(2-ethylhexyl) phosphoric acid). }\end{array}$ & $68.4 \%$ & - & $\begin{array}{l}\text { Yu et al. } \\
(2020)\end{array}$ \\
\hline $\begin{array}{l}\text { Cesium } \\
\qquad\left(\mathrm{Cs}^{+}\right)\end{array}$ & $\begin{array}{l}\text { Solvent extraction with 4-tert-butyl-2 ( } \alpha \text { - } \\
\text { methylbenzyl) phenol }\end{array}$ & $99.8 \%$ & $\begin{array}{l}\text { This extraction method is rapid and economically } \\
\text { feasible. }\end{array}$ & $\begin{array}{l}\text { Liu et al. } \\
\text { (2015) }\end{array}$ \\
\hline $\begin{array}{l}\text { Rubidium } \\
\left(\mathrm{Rb}^{+}\right)\end{array}$ & Sorption by ferrocyanides & $85 \%$ & - & $\begin{array}{l}\text { Vol'khin et } \\
\text { al. (2008) }\end{array}$ \\
\hline $\begin{array}{r}\text { Cesium } \\
\left(\mathrm{Cs}^{+}\right)\end{array}$ & $\begin{array}{l}\text { Sorption by nickel potassium ferrocyanide based } \\
\text { on hydrated } \mathrm{TiO}_{2} \text { in the presence of } \mathrm{Na}^{+}, \mathrm{K}^{+} \text {, and } \\
\mathrm{NH}_{4}^{+}\end{array}$ & $\begin{array}{l}\text { No effect of the single- } \\
\text { charged cations on the } \\
\text { adsorption of } \mathrm{Cs}^{+}\end{array}$ & $\begin{array}{l}\text { Capital and operational costs are less than other used } \\
\text { processes. It is profitable only in the case of high- } \\
\text { value minerals extraction. }\end{array}$ & $\begin{array}{l}\text { Voronina and } \\
\text { Semenishchev } \\
\text { (2013) }\end{array}$ \\
\hline
\end{tabular}

\subsubsection{The in silico ADMET/Model method}

This method involves the use of applying computational techniques, such as artificial intelligence, particularly machine learning methods. In silico refers to "in silicon", which is in connection to the silicon chips, present in all computer systems, hence the name. In recent times, the application of machine learning in the life sciences has grown particularly in the pharmaceutical industry (Klon et al., 2004; Lima et al., 2016). Machine learning methods help in predicting the toxicity and safety of compounds, both existing and modeled (computationally designed and not yet synthesized) compounds have helped in saving time, money and even reduce the exposure to danger all of which are absent when actually testing new and existing compounds experimentally. This method involves predicting the Absorption, Distribution, Excretion, and Toxicity (ADMET) properties of chemical compounds and hence is widely used in the drug (Chen et al., 2015; Smith, 2010). These ADMET properties predicted can be applied in LCIA by using the results from the categorized chemicals in the group-by-group method and predicting the eco-toxic effects on the models on which these machinelearning methods are based on provided they are aquatic organisms. Once the chemicals in the brine to be disposed of from desalination plants are known, they can be used to predict their eco-toxicity before being discharged into the sea. The predictions would help in the LCIA, also assess the risks involved, and hence recommend if the brine to be disposed of needs further treatment prior to being discharged back into the sea. In a very recent work performed by Suresh et al. (2018), where the Naïve Bayes algorithm was used to design a machine learningbased software for risk assessment. The results from such work can be translated into LCIA by making models of aquatic organisms and then using machine-learning algorithms to predict them. However, one has to bear in mind that this method would complement the group-by- group method to make it a very effective tool in assessing the ETP of brine disposed from desalination plants.

\subsubsection{Life cycle assessment case study on disposal or treatment of brine}

In the case study conducted by Salih et al. (2017), three different case scenarios were assumed, namely Case 1: pretreatment of brine for the removal of TSS and disposed of by deep-well disposal (DWD), Case 2: treatment by a near-ZLD treatment and then disposing of both the salt and brine by-products and Case 3: treatment by a near-ZLD treatment with the assumption of a beneficial utilization of the treatment by-products. This comparative LCA study mainly found that higher overall environmental impacts (EI) are generated in Case 1 from pretreatment than the DWD because of the chemical usage, disposal of sludge, and infrastructure construction. The largest portion of the overall EI of the pretreatment process is due to the coagulation process. Furthermore, other treatment options were investigated, and results showed that the disposal of the pretreated brine by DWD has the smallest EI. This can be attributed to the high-energy demand for the desalination of the pretreated brine (cases 2 and 3) resulting in the highest EI which are global warming potential and resource-fossil fuels. Because of the shortage in the required inventory data and characterization factors, the injected brine effect on the receiving geological formation was not considered. This study analyzed the water depletion for the three cases and suggested that $0.6 \mathrm{~m}^{3}-1.8 \mathrm{~m}^{3}$ fresh water for every $1.0 \mathrm{~m}^{3}$ of raw brine input can be used for the different disposal and treatment cases studied. For cases 2 and 3 , no global new wa ter gain wa s at tained despite producing around $0.8 \mathrm{~m}^{3}$ of purified water for every $1.0 \mathrm{~m}^{3}$ of raw brine input. For case 3 , when brine was desalinated and the byproducts were used, $0.6 \mathrm{~m}^{3}$ was the overall freshwater consumption balance. Results from the sensitivity analysis showed that cases 2 and 3 
Table 3

The chemical structure of chemical compounds commonly applied in IIPs (Chen et al., 2019).

Chemical compound

had the highest EI variability of $37 \%$ and $41 \%$, respectively. This is due to the high impact of energy variation in which significant differences in the values of EI can be observed if the thermal energy source changed from natural gas to fuels to renewable energy resources which have significantly the lowest EI.

\subsubsection{Effect of temperature and $\mathrm{pH}$ on brine management}

Yan et al. (2017) investigated the applicability of RO brine treatment hydrophobic polyvinylidene difluoride (PVDF) membrane under various feed temperatures. A significant increase of the MD flux with increasing the temperature of the feed was observed. This can be attributed to the greater vapor gradient. However, higher feed temperature lead to aggravated membrane scaling causing an accelerated sharp decrease in the flux as well as lower water recovery rate. Furthermore, increasing the feed temperature increased the thermal efficiency of the membrane while the reversibility of the flux decreased with increasing the feed temperature due to the formation of more scaling compact layers at higher temperatures. Elcik et al. (2020) used MED brine as a feed source for the MD system and investigated the influence of temperature on the scaling process. Since there is an exponential relationship between temperature and vapor pressure, results showed that increasing the feed temperature gradually from $50{ }^{\circ} \mathrm{C}$ to $80{ }^{\circ} \mathrm{C}$ leads to an increase in the permeate flux from $12.5 \mathrm{~kg} / \mathrm{m}^{2} \mathrm{~h}$ to $58 \mathrm{~kg} / \mathrm{m}^{2} \mathrm{~h}$. Furthermore, inorganic salts solubility is affected by the feed temperature as increasing the temperature reduces the salt solubility and the crystallization of salts will be more intensified at higher feed temperature. Chen et al. (2020), used t-BAMBP extractant for the recovery of $\mathrm{Rb}$ and $\mathrm{Cs}$ from brine and the results illustrated the importance of reaction temperature on the extraction process. Results showed that the extraction percentage had a drastic decrease when the temperature increased from $35{ }^{\circ} \mathrm{C}$ to $45^{\circ} \mathrm{Cwhich}$ can be due to the exothermic reaction of the extraction process as well as the decrease of distribution ratio as a result of the high temperature. Qu et al. (2020) studied brine droplets evaporation with various mass concentrations under different temperatures. Results showed that decreasing the temperature caused a decrease in the evaporation rate. Furthermore, the performed preliminary sensitivity analysis indicated that the evaporation rate was more sensitive to temperature. El-Naas et al. (2017) used a modified Solvay process without the use of ammonia for $\mathrm{CO}_{2}$ capturing as well as reducing the salinity of brine in the presence of calcium hydroxide. Results illustrated that increasing the reaction temperature lead to a decrease in sodium removal. Increasing the temperature from $10{ }^{\circ} \mathrm{C}$ to $50{ }^{\circ} \mathrm{C}$ caused a decline in sodium removal efficiency from $45.2 \%$ to less than $5 \%$.

Furthermore, Huo et al. (2020) demonstrated the use of a hybrid catalytic hydrogenation/membrane distillation process, which enables the ion exchange of waste brine reuse as well as captures nitrogen as a fertilizer product. In this work, a low-cost commercial $\mathrm{Ru} / \mathrm{C}$ catalyst was utilized to reduce nitrate to ammonia present in brine. Results revealed that rates of ammonia mass transfer through the gas-permeable membrane increased with increasing the feed solution $\mathrm{pH}$. Furthermore, the treated brine $\mathrm{pH}$ is usually increased by the catalytic nitrate hydrogenation reaction, thus facilitating the recovery of ammonia in the subsequent membrane distillation step. Chancellor et al., 2016, evaluated the effect of superabsorbent polymer (SAB) when introduced to the brine solution that contains calcium ions at different $\mathrm{pH}$ values. Results showed that polymer precipitation with calcium ions could be significantly inhibited by a very low $\mathrm{pH}$ value. Furthermore, Zoppas et al. (2018) applied catalytic reduction for the treatment of brine with high nitrate concentration by the employment of low noble metal loading in the catalyst (Pd 1\%, in 25\%) supported on alumina. Results indicated the viability of the catalytic reduction technique for the treatment of nitrate brine. It wa s proved that controlling the $\mathrm{pH}$ of the process is crucial due to the direct influence on the catalytic activities as well as the selectivity to ammonium that is an undesirable product.

\section{Exposure and usage}

Furthermore, RO has been used as a potential and effective technology for providing clean water and it has become the most used alternative process especially in the regions that are suffering from a shortage of water supplies (Petersková et al., 2012; Stacklin, 2012). It converts seawater into potable clean water through a desalination process that would generate a concentrated brine effluent as a waste. The brine waste is normally discharged back into the sea and becoming diluted with seawa ter (Jeppesen et al., 2009). However, the potential environmental challenges of the RO desalination plants have grown in addition to the thermal distillation plants. RO desalination plants consume huge volumes of water and dispose of a heavy brine concentrate back into the environment. However, the RO destination plants' brine waste with a high salt concentration, minerals, and other pollutants is usually disposed into the sea via specific channels as hypersaline brine. RO concentrate is usually disposed of in various ways; surface water disposal is one of these ways. Additional methods would be through deep well injection, ponds, and land application (Ly et al., 2013; Breunig et al., 2013). The ZLD systems are considered one of the new advances and desirable systems that are aimed to advance process the RO concentrate to avoid discharge it into surface waters, effective re-use of water, and to produce dry salts. However, scale formation, owing to the precipitation of alkaline earth metals, in highly concentrated brines is still a challenging technical problem (Davenport et al., 2018). Qatar Petroleum and its partner Shell are currently working to achieve a model capability that would have zero liquid discharge.

The effect of the brine disposal on the sea environment is still principally unidentified; however, it is normally assumed that the brine wa ste shall eventually be diluted into the sea and can be harmful to marine life and on the composition and distribution of biota. Other potential environmental impacts are the stratification problem as a result of increasing salinity and density, eutrophication problem because of phosphate supplementation, discoloration owing to high iron(III) concentration with high suspended solids and turbidity. Nonetheless, the desalination plants have always been taken special care to regulate the brine waste outlets. 
Table 4

Application of IIPs to extract the different type of potentially toxic metals.

\begin{tabular}{|c|c|c|c|c|c|c|}
\hline Technology & $\begin{array}{l}\text { Toxic } \\
\text { Metal }\end{array}$ & $\begin{array}{l}\text { Functional } \\
\text { monomer }\end{array}$ & Cross-linking ag ent & Initia tor & Application(s) & References \\
\hline Pb-IP & $\begin{array}{l}\text { Lead II }[\mathrm{Pb} \\
\text { (II)] }\end{array}$ & $\begin{array}{l}\text { 4-vinyl } \\
\text { pyridine (VP) }\end{array}$ & $\begin{array}{l}\text { Ethyleneglycoldimethacry la te } \\
\text { (EGDMA) }\end{array}$ & $\begin{array}{l}2,2^{\prime}- \\
\text { azobis is obutyr onitrile } \\
\text { (AIBN) }\end{array}$ & $\begin{array}{l}\text { Recognizing lead/pre-concentration and removal } \\
\text { from water samples. }\end{array}$ & $\begin{array}{l}\text { Khaj eh et } \\
\text { al. (2011) }\end{array}$ \\
\hline $\mathrm{Cu}-\mathrm{IP}$ & $\begin{array}{l}\text { Copper } \\
(\mathrm{Cu})\end{array}$ & $\begin{array}{l}\text { Methacrylic } \\
\text { acid (MAA) }\end{array}$ & $\begin{array}{l}\text { Ethyleneglycoldimethacry la te } \\
\text { (EGDMA) }\end{array}$ & $\begin{array}{l}2,2^{\prime}- \\
\text { azobis is obutyr onitrile } \\
\text { (AIBN) }\end{array}$ & $\begin{array}{l}\text { In wastewater, treatment to adsorb particular heavy } \\
\text { metal contaminant and concurrently determ ines } \mathrm{pH} \\
\text { sensitivity traits. }\end{array}$ & $\begin{array}{l}\text { Yuan et } \\
\text { al. (2015) }\end{array}$ \\
\hline Ni-IP & Nickel (Ni) & $\begin{array}{l}\text { Methacrylic } \\
\text { acid (MAA) }\end{array}$ & $\begin{array}{l}\text { Ethyleneglycoldimethacry la te } \\
\text { (EGDMA) }\end{array}$ & $\begin{array}{l}2,2^{\prime}- \\
\text { azobis is obutyr onitrile } \\
\text { (AIBN) }\end{array}$ & $\begin{array}{l}\text { In the adsorption of } \mathrm{Ni}^{2+} \text { ions from the water } \\
\text { environment. }\end{array}$ & $\begin{array}{l}\text { Kumar et } \\
\text { al. (2019) }\end{array}$ \\
\hline Cd-IP & $\begin{array}{l}\text { Cadmium } \\
\text { (Cd) }\end{array}$ & $\begin{array}{l}\text { Methacrylic } \\
\text { acid (MAA) }\end{array}$ & $\begin{array}{l}\text { Ethylene glycol } \\
\text { dimethacry la te (EGDMA) }\end{array}$ & $\begin{array}{l}2,2^{\prime}- \\
\text { azobis is obutyr onitrile } \\
\text { (AIBN) }\end{array}$ & $\begin{array}{l}\text { Employing the novel cadmium ion-imprinted } \\
\text { polymers to remove cadmium (II) from wastewater }\end{array}$ & $\begin{array}{l}\text { Xi et al. } \\
(2015)\end{array}$ \\
\hline Cr-IP & $\begin{array}{l}\text { Chromi um } \\
(\mathrm{Cr}(\mathrm{VI}))\end{array}$ & $\begin{array}{l}2- \\
\text { vinylpyridine }\end{array}$ & $\begin{array}{l}\text { Ethylene glycol } \\
\text { dimethacry la te (EGDMA) }\end{array}$ & $\begin{array}{l}1,1^{\prime} \text {-azobis } \\
\text { (cyclohexa necarbonitrile) }\end{array}$ & $\begin{array}{l}\text { In the removal/adsorption of chromium (VI) from } \\
\text { nega tive metals (anions) and sulfate in aqueous } \\
\text { environments }\end{array}$ & $\begin{array}{l}\text { Paka de et } \\
\text { al. (2011) }\end{array}$ \\
\hline $\mathrm{Hg}-\mathrm{IP}$ & $\begin{array}{l}\text { Mercury } \\
{[\mathrm{Hg}(11)]}\end{array}$ & $\begin{array}{l}\text { Methacrylic } \\
\text { acid (MAA) }\end{array}$ & $\begin{array}{l}\text { Ethylene glycol } \\
\text { dimethacry la te (EGDMA) }\end{array}$ & $\begin{array}{l}2,2^{\prime}- \\
\text { azobis is obutyr onitrile } \\
\text { (AIBN) }\end{array}$ & $\begin{array}{l}\text { To determ ine the concentration level of mercury (II) } \\
\text { in natural water (river, lagoon, and mineral water) } \\
\text { and subsequently using it as an adsorbent for the } \\
\text { removal. }\end{array}$ & $\begin{array}{l}\text { Lins et al. } \\
\text { (2019) }\end{array}$ \\
\hline As-IP & $\begin{array}{l}\text { Arsenic [As } \\
\text { (lll)], [As } \\
\text { (IV)] }\end{array}$ & $\begin{array}{l}\text { Methacrylic } \\
\text { acid (MAA) }\end{array}$ & $\begin{array}{l}\text { Ethylene glycol } \\
\text { dimethacry la te (EGDMA 98) }\end{array}$ & $\begin{array}{l}2,2^{\prime}- \\
\text { azobis is obutyr onitrile } \\
\text { (AIBN) }\end{array}$ & $\begin{array}{l}\text { In the selective removal of arsenic from some } \\
\text { chosen water, rice, and vegetables }\end{array}$ & $\begin{array}{l}\text { Jalilian et } \\
\text { al. (2019) }\end{array}$ \\
\hline
\end{tabular}

Recently, attention has been focused on recovering valuable metals from the discharged concentrated brine waste. Certainly, attaining marketable products from the discharged concentrated brine would offer an economic benefit and reducing the whole desalination costs.

Owing to the environmental problems and challenges that might be caused by brine disposal, various methodological techniques have been investigated for metal recovery gaining the benefit of their reasonably high concentrations in brine. However, the assessment criteria for the metal extraction would be economic, concentration, and other physicochemical criteria, and technical and extraction procedures criteria.

Recovery of valuable and rare metals from their novel and abundant sources around the globe can increase its profitability by decreasing the water production cost as well as limiting the environmental issues associated with brine disposal (Katal et al., 2020; Loganathan et al., 2017). How ever, technologies used for metal recovery are still undeveloped and require more investigation to enhance achievement in extraction steps and obtain a suitable level of improvement to be used at the industrial scale. Extraction methodologies of alkali and alkaline metals such as sodium, magnesium, potassium, and bromide are well documented. These include precipitation, ion exchange, adsorption, membrane separation, and others. However, trace metal recovery from concentrated brine may face difficulties concerning low metal concentration, limited selectivity, and the complexity of the brine system. Many investiga tors have at tempted to overcome the above-mentioned difficulties, but quantita tively trace metal recovery remains a challenging task (Guerra et al., 2011; Le Dirach et al., 2005; Morillo et al., 2014).

The literature showed that concentrated brine contains important concentrations of various valuable metals such as lithium $\left(\mathrm{Li}^{+}\right)$, cesium $\left(\mathrm{Cs}^{+}\right)$, and rubidium $\left(\mathrm{Rb}^{+}\right)$(Le Dirach et al., 2005; Chen et al., 2020; Li et al., 2017; Naidu et al., 2018). Our preliminary investigation has shown that the concentrations of $\mathrm{Rb}^{+}$and $\mathrm{Cs}^{+}$are 0.194 and $0.0008 \mathrm{mg} / \mathrm{L}$, respectively. This represents the potential usage of developing recovery methodology for the significant amount of $\mathrm{Rb}^{+}$and $\mathrm{Cs}^{+}$present at the concentrated brine. It is, therefore, necessary to develop an appropriate methodology to recover $\mathrm{Rb}^{+}$and $\mathrm{Cs}^{+}$from the concentrated brine, with an emphasis on the associated efficiency, costs, and environmental impacts. Various natural and synthetic materials have been investigated for metal recovery from wa ste such as zeolites and synthetic ion-exchangers. How ever, these materials seem to be not economically valuable as they are associated with low efficiency and high operational cost. The employment of biological materials in recovering valuable metals from brine systems would have a potential substitute for conventional methodologies with high efficiency (Gurung et al., 2013; Rodriguez-Rojas et al., 2020).

Moreover, $\mathrm{Rb}^{+}$and $\mathrm{Cs}^{+}$have unique chemical and physical characteristics. It is acknowledged that the resources of $\mathrm{Rb}^{+}$and $\mathrm{Cs}^{+}$are globally rare. They have been used in various key industries such as fiber optics, lamps, night vision devices, for $\mathrm{Rb}^{+}$; aeronautics, high-pressure oil, and gas wells for $\mathrm{Cs}^{+}$(Loganathan et al., 2017). Therefore, further scientific research on $\mathrm{Rb}^{+}$and $\mathrm{Cs}^{+}$is a dire need. Brine is considered as one of the noteworthy resources of $\mathrm{Rb}^{+}$and $\mathrm{Cs}^{+}$(Li et al., 2017; Shahmansouri et al., 2015; Mavukkandy et al., 2019). The richness of $\mathrm{Rb}^{+}$and $\mathrm{Cs}^{+}$in the concentrated brine depends on its nature. How ever, as the physical and chemical properties of $\mathrm{Na}^{+}, \mathrm{K}^{+}, \mathrm{Rb}^{+}$, and $\mathrm{Cs}^{+}$are similar, the separation of $\mathrm{Rb}^{+}$and $\mathrm{Cs}^{+}$from the brine system would be difficult (Ye et al., 2009). Consequently, the development of a simple, selective, and practical method for the separation of $\mathrm{Rb}^{+}$and $\mathrm{Cs}^{+}$from concentrated brine is of importance.

\subsection{Metals recovery methods}

Few investigations have been implemented to develop recovery methodologies for $\mathrm{Rb}^{+}$and $\mathrm{Cs}^{+}$from brine systems such as membrane, adsorption, ion exchange, chemical precipitation, and coagulation methodologies (Chen et al., 2017; Gurung et al., 2013; Ye et al., 2009). However, these methodologies have their advantages and boundaries in the application. For example, chemical precipitation is inadequate when the metal concentration is low. This involves a great number of chemicals and generating huge amounts of sludge that will necessita te further treatment. The efficiency of the other methodologies in metal recovery such as ion exchange and membrane technologies would be high with low chemical consumption and high metal selectivity. However, the operation costs are expensive (Bao et al., 2017). Table 2 illustrates various metal recovery methods from brine.

\subsubsection{Adsorption}

Metal adsorption on an adsorbent has the benefit of liquid-liquid extraction. The latter requires mixing and settling. Metals in brine are 2.5 times higher than their concentration in seawa ter, which results in making their crystallization prior to or after the adsorption process more favorable for further concentration (Loganathan et al., 2017). 
Table 5

Comparison of the advantages, limitations, as well as cost and energy requirements of brine treatment technologies.

\begin{tabular}{|c|c|c|c|c|c|}
\hline Technology & Technologies' maturity level & Technical shortcomings & Economic scalability prospects & $\begin{array}{l}\text { Treatable } \\
\text { range of brine } \\
\text { salinity }\end{array}$ & References \\
\hline VSEP & $\begin{array}{l}\text { Distribution is not affected by } \\
\text { colloids, solid suspension, } \\
\text { availability, or salt solubility - } \\
\text { Ability to reduce the occurrence } \\
\text { of fouling and scaling that is } \\
\text { comm on with conventional RO } \\
\text { system. }\end{array}$ & $\begin{array}{l}\text { Maintenance of oscillatory } \\
\text { vibration of a tensional } \\
\text { spring requires energy that } \\
\text { must be considered. }\end{array}$ & $\begin{array}{l}\text { Costs are determ ined by considering the feed water } \\
\text { factors (BOD, boron, chloride, fluoride, TDS, TSS, } \\
\text { sulfate, TN, TOC as well as associated energy } \\
\text { consumption. }\end{array}$ & & $\begin{array}{l}\text { Petala et } \\
\text { al. (2006); } \\
\text { Zouboulis } \\
\text { et al. } \\
\text { (2019); } \\
\text { Lozier et } \\
\text { al. (2007) }\end{array}$ \\
\hline $\begin{array}{l}\text { ED, EDR, and } \\
\text { EDM }\end{array}$ & $\begin{array}{l}\text { The membra ne fouling is often } \\
\text { controlled by the polarity } \\
\text { reversal. It allows performance } \\
\text { at higher feed water recovery } \\
\text { with small-scale control } \\
\text { chemicals. } \\
\text { Contrary to the other membrane } \\
\text { process utilized in drinkable } \\
\text { water and reuse, water does not } \\
\text { pass through the EDR, but the } \\
\text { ions do. }\end{array}$ & $\begin{array}{l}\text { The removal of poorly } \\
\text { ionized solute, as well as } \\
\text { particulates, is not } \\
\text { eliminated and the removal } \\
\text { of pathogens from the } \\
\text { process is not credited. }\end{array}$ & Cost of energy increases with the TDS of feed brine & $\begin{array}{l}\text { High sa linity } \\
\text { limit (> } \\
100,000 \mathrm{mg} / \mathrm{L})\end{array}$ & $\begin{array}{l}\text { Giwa et al. } \\
\text { (2017); } \\
\text { Morillo et } \\
\text { al. (2014); } \\
\text { Lozier et } \\
\text { al. (2007); } \\
\text { Pram anik } \\
\text { et al. } \\
\text { (2017) }\end{array}$ \\
\hline FO & $\begin{array}{l}\text { Applied pressure is not essential } \\
\text { for the osmotically driven } \\
\text { process. Good for high salinity } \\
\text { desalination. The energy } \\
\text { consumption is less when used } \\
\text { together with RO. The waste } \\
\text { heat source is useful for the } \\
\text { regenera tion of the drawn } \\
\text { solution. The feed water } \\
\text { recovery is high. The fouling } \\
\text { potential is low because applied } \\
\text { pressure is lacking. }\end{array}$ & $\begin{array}{l}\text { Full-scale installations are } \\
\text { limited. The selection of } \\
\text { optimal osmotic ag ents } \\
\text { (draw solution) is very } \\
\text { challenging. The rates of } \\
\text { flux are less than RO } \\
\text { causing higher membra ne } \\
\text { ar ea requirement. FO } \\
\text { applications require } \\
\text { membrane specific. }\end{array}$ & $\begin{array}{l}\text { In general, this technology is less energy-intensive } \\
\text { compared to other technologies. The costs are } \\
\text { influenced by the type of technology in use. In wholly } \\
\text { FO applications that involve gaseous mixtures as } \\
\text { draw solution, the ma in cost needed for recovery of } \\
\text { the draw solution will be the thermal energy. In } \\
\text { FO/RO hybridization utilizing reuse water to feed RO } \\
\text { and FO for seawater desalination, the desalinating } \\
\text { water cost will be less er because less electrical } \\
\text { energy will be needed in the RO stage because of the } \\
\text { dilution of feed seawater. }\end{array}$ & $\begin{array}{l}\text { High sa linity } \\
\text { limit (> } \\
200,000 \mathrm{mg} / \mathrm{L})\end{array}$ & $\begin{array}{l}\text { Morillo et } \\
\text { al. (2014); } \\
\text { Martinetti } \\
\text { et al. } \\
\text { (2009); } \\
\text { Chung et } \\
\text { al., 2012a, } \\
2012 \text { b; } \\
\text { Tow and } \\
\text { McGovern } \\
\text { (2015) }\end{array}$ \\
\hline WAIV & $\begin{array}{l}\text { The evaporation ra te increases } \\
\text { ten times and land requirements } \\
\text { ar e relatively reduced when } \\
\text { compar ed to the conventional } \\
\text { evaporation ponds method. }\end{array}$ & $\begin{array}{l}\text { Groundwater pollution is } \\
\text { not avoidable }\end{array}$ & $\begin{array}{l}\text { The cost of operating WAIV is low because its main } \\
\text { driving force is air dryness and allows this } \\
\text { technology to be suitable for areas as sociated with } \\
\text { high costs of energy and air dryness. }\end{array}$ & & $\begin{array}{l}\text { Mo rillo et } \\
\text { al. (2014); } \\
\text { Ma cedonio } \\
\text { et al. } \\
\text { (2011) }\end{array}$ \\
\hline $\begin{array}{l}\text { Brine } \\
\text { crystallizers }\end{array}$ & $\begin{array}{l}\text { The technology is used almost } \\
\text { everywhere because it uses fossil } \\
\text { fuels and get rid of clim ate } \\
\text { requir ements compared to solar } \\
\text { energy }\end{array}$ & $\begin{array}{l}\text { The multiple equipment } \\
\text { modules are required } \\
\text { because of larg e systems } \\
\text { that nega tively affect the } \\
\text { economy of scale using } \\
\text { Evaporative Crystallization } \\
\text { (EC) }\end{array}$ & $\begin{array}{l}\text { The high cost of consumed energy is predominant, } \\
\text { with the approximated final cost of } 0.095 \text { euro per } \\
\text { kilogram of evaporated brine. It is considered an } \\
\text { energy-intensive technology. }\end{array}$ & & $\begin{array}{l}\text { Morillo et } \\
\text { al. (2014); } \\
\text { Ji et al. } \\
\text { (2010); } \\
\text { Pram anik } \\
\text { et al. } \\
\text { (2017) }\end{array}$ \\
\hline $\begin{array}{l}\text { Brine } \\
\text { concentrator }\end{array}$ & $\begin{array}{l}\text { It is peculiar with the production } \\
\text { of distilled water of great } \\
\text { quality that subsequently leads } \\
\text { to a reduction in the volume of } \\
\text { the final brine. The ma nagement } \\
\text { of reject bribe is easier because } \\
\text { of the cooling and concentration } \\
\text { systems }\end{array}$ & $\begin{array}{l}\text { Char acterized by serious } \\
\text { challenges in the setting up } \\
\text { and ma nagement of both } \\
\text { intake and outfall } \\
\text { structures. The solubility of } \\
\mathrm{Na}^{+} \text {salts, the relative } \\
\text { concentration of } \mathrm{SO}_{4}^{2-}, \mathrm{Cl}^{-} \text {, } \\
\text { and the boiling point } \\
\text { elevation of the brine. }\end{array}$ & Energy-intensive technology & & $\begin{array}{l}\text { Morillo et } \\
\text { al. (2014); } \\
\text { Ci pollina } \\
\text { et al. } \\
\text { (2011); } \\
\text { Pram anik } \\
\text { et al. } \\
\text { ( } 2017)\end{array}$ \\
\hline MED & $\begin{array}{l}\text { Operating temperature is very } \\
\text { high reaching up to } 172{ }^{\circ} \mathrm{C} \text { with } \\
\text { the possibility of producing low } \\
\text { compression work, heat transfer } \\
\text { with a small area, and } \\
\text { compress or size reduction as } \\
\text { rewards }\end{array}$ & $\begin{array}{l}\text { Pretreatment stages were } \\
\text { essential to minimize the } \\
\text { concentration of silica and } \\
\text { stop the form ation of scale } \\
\text { on the surfaces of the heat } \\
\text { exchanger, which makes the } \\
\text { process complicated. }\end{array}$ & $\begin{array}{l}\text { Costs are determined based on the thermo- } \\
\text { compress or and the efficiency of technology within } \\
\text { the stag es. Can be considered as energy-intensive } \\
\text { technology, but less than BC and BCr. }\end{array}$ & & $\begin{array}{l}\text { Giwa et al. } \\
\text { (2017); } \\
\text { Ma cedonio } \\
\text { et al. } \\
\text { (2011) }\end{array}$ \\
\hline MD & $\begin{array}{l}\text { Applied pressure is absent. } \\
\text { Rejection capacity with } \\
\text { nonvolatile removal is high. } \\
\text { When the vacuum is used, the } \\
\text { operating temperature is at the } \\
\text { lowest. It allows the use of } \\
\text { plastic ma terials to prevent } \\
\text { corrosion. It perm its the use of } \\
\text { various energy sources (e.g. } \\
\text { solar energy, heat energy, and } \\
\text { wind energy) }\end{array}$ & $\begin{array}{l}\text { Only studies on the bench - } \\
\text { scale or pilot - scale were } \\
\text { conducted. Specifically, } \\
\text { membra nes and modules } \\
\text { designed for MD are } \\
\text { lacking. When the } \\
\text { membra ne is wetted, it } \\
\text { causes fouling of } \\
\text { hydrophobic membranes, } \\
\text { which is a critical issue. } \\
\text { Feedwater pretreatment is } \\
\text { required from the source. }\end{array}$ & $\begin{array}{l}\text { Yet to be known. Technology still in } \\
\text { piloting/demonstration or bench scale. Waste heat } \\
\text { source availability to heat feed water stream will } \\
\text { determ ine the costs. } \\
\text { Higher energy consumption relative to energy use of } \\
\text { RO, but less than traditional evaporation and } \\
\text { crystallization systems. Furtherm ore, it could be } \\
\text { coupled with a solar collector system, which reduces } \\
\text { energy consumption. }\end{array}$ & $\begin{array}{l}\text { High sa linity } \\
\text { limits (> } \\
200,000 \mathrm{mg} / \mathrm{L})\end{array}$ & $\begin{array}{l}\text { Martinetti } \\
\text { et al. } \\
\text { (2009); } \\
\text { Subram ani } \\
\text { et al. } \\
\text { (2015);. Ji } \\
\text { et al. } \\
\text { ( } 2010) \text {; } \\
\text { Pram anik } \\
\text { et al. } \\
\text { (2017) }\end{array}$ \\
\hline
\end{tabular}


Table 6

Compilation of brine treatment technologies in various studies.

\begin{tabular}{|c|c|c|c|}
\hline Technology & Productivity & $\begin{array}{l}\text { Operating } \\
\text { Conditions }\end{array}$ & References \\
\hline $\begin{array}{l}\text { Forward } \\
\text { Os mosis }\end{array}$ & $\begin{array}{l}\text { After } 18 \mathrm{~h} \text {, maximum } \\
\text { water recovery attains } \\
76 \% \text {; and salt rejection } \\
\text { stood at } 99.7 \%\end{array}$ & $\begin{array}{l}\text { FO is set up on a } \\
\text { labora tory scale; } \\
\text { Cellulose acetate } \\
\text { as ym metric (CA) } \\
\text { and Polyam ide } \\
\text { composite (PA) } \\
\text { membra nes; } \\
\text { Sodium Chloride, } \\
\text { Deionized water; } \\
\text { Diluted fructose; } \\
\text { Feed solution }\end{array}$ & $\begin{array}{l}\text { Tang et al. } \\
\text { (2008) }\end{array}$ \\
\hline $\begin{array}{l}\text { Reverse } \\
\text { Os mosis and } \\
\text { Forward } \\
\text { Osmosis }\end{array}$ & $\begin{array}{l}\text { The water recovery for } \\
\text { brine } \mathrm{A} \text { is approximately } \\
86 \% \text { and } 60 \% \text { for brine } \mathrm{B}\end{array}$ & $\begin{array}{l}\text { RO - FO hybrid } \\
\text { system; TDS in } \\
\text { brine } \mathrm{A} \text { is } \\
7500 \mathrm{mg} / \mathrm{L} \text { and } \\
17,500 \mathrm{mg} / \mathrm{L} \text { in } \\
\text { brine } \mathrm{B} \text {; NaCl in } \\
\text { draw solution is } \\
50 \pm 2 \mathrm{~g} / \mathrm{L} \text {; } \\
\text { Cellulose } \\
\text { triacetate (CTA); } \\
\text { operating } \\
\text { temperature is } \\
23+-2^{\circ} \mathrm{C}\end{array}$ & $\begin{array}{l}\text { Martinetti et } \\
\text { al. (2009) }\end{array}$ \\
\hline $\begin{array}{l}\text { Forward } \\
\text { Os mosis }\end{array}$ & $\begin{array}{l}\text { The water fluxes from PA } \\
\text { and CTA membranes are } \\
0.0315 \mathrm{~L}\left(\mathrm{~m}^{2}\right)^{-1} \cdot \mathrm{m} \text { to } \\
0.56 \mathrm{~L}\left(\mathrm{~m}^{2}\right)^{-1} \cdot \mathrm{m} \text { and } \\
\left.0.0315 \mathrm{~L}^{2} \mathrm{~m}^{2}\right)^{-1} \cdot \mathrm{m} \text { to } \\
0.56 \mathrm{~L}\left(\mathrm{~m}^{2}\right)^{-1} \cdot \mathrm{m} \\
\text { respectively. }\end{array}$ & $\begin{array}{l}\text { FO system; } \\
\text { membrane - PA \& } \\
\text { CTA; } 35 \mathrm{~g} / \mathrm{L}- \\
200 \mathrm{~g} / \mathrm{L} \text { TDS in } \\
\text { draw solution; } \\
5 \mathrm{~g} / \mathrm{L}-15 \mathrm{~g} / \mathrm{L} \text { in } \\
\text { feed solution }\end{array}$ & $\begin{array}{l}\text { Martinetti et } \\
\text { al. (2009) }\end{array}$ \\
\hline VSEP & $\begin{array}{l}80 \% \text { recovery of } \\
\text { concentrate }\end{array}$ & VSEP system & $\begin{array}{l}\text { Delg ado } \\
\text { (2009) }\end{array}$ \\
\hline DT & $\begin{array}{l}\text { Concentrate recovery is } \\
50-80 \%\end{array}$ & $\begin{array}{l}\text { DT filtrations; } \\
\text { conditions of flux } \\
\text { differ: } \\
30 \mathrm{~L}\left(\mathrm{~m}^{2}\right)^{-1} \cdot \mathrm{h}- \\
34 \mathrm{~L}\left(\mathrm{~m}^{2}\right)^{-1} \cdot \mathrm{h}\end{array}$ & $\begin{array}{l}\text { (Subram ani } \\
\text { et al., } \\
\text { 2011), }\end{array}$ \\
\hline EDM & $\begin{array}{l}\text { Water recovery attains } \\
99.9 \%\end{array}$ & $\begin{array}{l}\text { EDM system; TDS } \\
\text { in the sa mples of } \\
\text { concentrate ranges } \\
\text { between } 3000 \text { and } \\
16,000 \mathrm{mg} / \mathrm{L}\end{array}$ & \\
\hline VSEP & $\begin{array}{l}\text { Final water recovery is } \\
75-93 \%\end{array}$ & $\begin{array}{l}\text { VSEP system; } \\
\text { cross-flow } \\
\text { operation is } \\
\text { continuous; } 50- \\
\left.100 \text { flux } \mathrm{L}^{2} \mathrm{~m}^{2}\right)^{-1} \cdot \mathrm{h}\end{array}$ & $\begin{array}{l}\text { Subram ani } \\
\text { et al. (2012) }\end{array}$ \\
\hline ED & $\begin{array}{l}\text { COD, total nitrogen }(\mathrm{N}) \text {, } \\
\text { and total phosphorus }(\mathrm{P}) \\
\text { removal stands at } 20 \% \text {, } \\
32 \% \text {, and } 32 \% \\
\text { respectively }\end{array}$ & $\begin{array}{l}\text { Combined ED and } \\
\text { Willow field }\end{array}$ & $\begin{array}{l}\text { Ghys elbrecht } \\
\text { et al. (2012) }\end{array}$ \\
\hline \multirow[t]{2}{*}{ ED } & $\begin{array}{l}\text { Removal of Calcium } \\
\text { approxim ately } 70-80 \% \text {. }\end{array}$ & $\begin{array}{l}\text { ED system, pH is } \\
\text { approximately } 11, \\
\text { pellet reactor } \\
\text { treatment. }\end{array}$ & $\begin{array}{l}\text { Tran et al. } \\
\text { (2012) }\end{array}$ \\
\hline & $\begin{array}{l}\text { Removal of Calcium and } \\
\text { Magnesium: } 95 \% \text { and } 5- \\
25 \% \text {, respectively }\end{array}$ & $\begin{array}{l}\text { ED system, pH is } \\
\text { approximately } \\
11.5, \text { pellet } \\
\text { reactor treatment }\end{array}$ & \\
\hline $\begin{array}{l}\text { Brine } \\
\text { Concentrator }\end{array}$ & Final water recovery $99 \%$ & $\begin{array}{l}\text { The Aquasel's } \\
\text { system - A non- } \\
\text { thermal brine } \\
\text { concentrator } \\
\text { (NTBC) }\end{array}$ & $\begin{array}{l}\text { Peng et al. } \\
\text { (2012) }\end{array}$ \\
\hline EDR & Final water recovery $97 \%$ & EDR system & $\begin{array}{l}\text { Xu et al. } \\
(2013)\end{array}$ \\
\hline EDR & $\begin{array}{l}\text { Final water recovery } \\
98.9 \%\end{array}$ & $\begin{array}{l}\text { Combine EDR and } \\
\text { Ion exchange } \\
\text { pretreatment }\end{array}$ & $\begin{array}{l}\text { (He et al., } \\
\text { 2013), }\end{array}$ \\
\hline
\end{tabular}

Table 6 (continued)

\begin{tabular}{|c|c|c|c|}
\hline Technology & Productivity & $\begin{array}{l}\text { Operating } \\
\text { Conditions }\end{array}$ & References \\
\hline $\begin{array}{l}\text { Forward } \\
\text { Osmosis and } \\
\text { Reverse } \\
\text { Osmosis }\end{array}$ & $\begin{array}{l}\text { Energy consumption by } \\
\text { FO drop by } 3 \% \text { in FO - } \\
\text { RO (Nicoli's model); the } \\
\text { thermally operated FO } \\
\text { plot reduced energy } \\
\text { consumption by } 21 \%\end{array}$ & $\begin{array}{l}\text { FO pilot method } \\
\text { coupled with RO } \\
\text { regeneration } \\
\text { (FO/RO); thermal } \\
\text { source regenera ted } \\
\text { FO; } 7 \% \text { of } \mathrm{NaCl} \\
\text { draw; fall in } \\
\text { hydraulic pressure } \\
\text { in feed as well as } \\
\text { draw streams to } \\
\text { just } 2 \text { bar }\end{array}$ & $\begin{array}{l}\text { Tow \& } \\
\text { McGovern } \\
(2015)\end{array}$ \\
\hline MSF & $\begin{array}{l}\text { The discharge density is } \\
1022.9 \mathrm{~kg} / \mathrm{m}^{3},< \\
\text { am bient with thermal } \\
\text { energy discharge of } \\
101.52 \mathrm{GWh} / \mathrm{d} \text {. The } \\
\text { seaw ater intake to the } \\
\text { product ratio (Mc/D) is } \\
9.64 \\
{\left[\mathrm{Mc}=11.352 \mathrm{Mm}^{3} / \mathrm{d}\right]} \\
\text { while the reject stream } \\
\text { (Mc - D) is } 10.152 \mathrm{Mm}^{3} / \mathrm{d}\end{array}$ & MSF & $\begin{array}{l}\text { Darwish et } \\
\text { al. (2013) }\end{array}$ \\
\hline Pervaporation & $\begin{array}{l}\text { The salt rejection is } \\
\text { approximately } 99 \%\end{array}$ & $\begin{array}{l}\text { Setup of } \\
\text { pervaporation } \\
\text { water } \\
\text { desalination; up } \\
\text { to } 75{ }^{\circ} \mathrm{C} \text { of } \\
\text { temperature; salt } \\
\text { concentration of } \\
\text { brine stands at } \\
7.5 \mathrm{wt} \% \text { and } \\
10 \mathrm{wt} \% \text {. }\end{array}$ & $\begin{array}{l}\text { (Yacou et } \\
\text { al., 2015), }\end{array}$ \\
\hline
\end{tabular}

The chelating adsorption appears to be the appropriate and efficient methodology for the $\mathrm{Rb}^{+}$and $\mathrm{Cs}^{+}$recovery from the concentrated brine. Since adsorption may be triggered due to the competition betw een metals in the brine, it has been suggested that chemically modified materials with specific inorganic compounds would selectivity recover specific ion(s) of concern. The material could be ion-exchange resin, activated carbon, and cellulose (Diallo et al., 2015; Loganathan et al., 2017; Mavukkandy et al., 2019). These results in the development of novel materials to improve the adsorption characteristics of the modified material that can enhance their mechanical properties. Solid adsorbents with high selectivity and removal capacity toward specific metals are essential to various fields such as separation, purification, and treatment. Adsorbent selectivity could be succeeded by physical and/or chemical modification of its surface.

Our previous researches have been focusing on the development of using natural biological origin resources as a substitute to common adsorbents for metal elimination and recovery (Al-Ghouti et al., 2010, 2013). It was concluded that the modified date pits by various modification methodologies were active in removing various metals from water. Gurung et al. (2013) showed in their studies that polyphenolic resins could selectively recover $\mathrm{Cs}^{+}$from the brine system. The phenolic $\mathrm{OH}$ groups acted as a metal eliminator at low $\mathrm{pH}$ to recover metals for water. The possible effectiveness of date pits as a low-cost adsorbent for various metals and organic compounds was proven earlier (AlGhouti et al., 2013). The metal ion would form a stable complex with the $\mathrm{OH}$-phenolic groups available in date pits. The date pits comprise of three main groups, specifically cellulose, hemicellulose, and lignin. The main functional groups of cellulose and hemicellulose are hydroxyl, ether, and carbonyl. Lignin acts as a strengthening matrix betw een cellulose and hemicellulose (Al-Ghouti et al., 2010).

A modification of date pits for the recovery of $\mathrm{Rb}^{+}$and $\mathrm{Cs}^{+}$from the concentrated brine seems to be a highly encouraging approach. However, to the best of our knowledge, no studies have investigated the adsorption and recovery behavior of date pits towa rds $\mathrm{Rb}^{+}$and $\mathrm{Cs}^{+}$. $\mathrm{Na}^{+}$is the most available interfering ion with $\mathrm{Rb}^{+}$and $\mathrm{Cs}^{+}$from 
concentrated brine. Vol'khin et al. (2008) reported that the adsorption techniques would be advisable to recover the $\mathrm{Rb}^{+}$brine system. Ferrocyanides [hexacyanoferrates(II)] of ( $\mathrm{Cu}, \mathrm{Ni}$, and $\mathrm{Zn})$ can selectively adsorb various ions such as $\mathrm{Rb}^{+}, \mathrm{Cs}^{+}$, and $\mathrm{Tl}^{+}$from brine system with high separation coefficient $\left(\mathrm{K}_{\mathrm{d}}\right)$ for $\mathrm{Rb}^{+}$and $\mathrm{K}^{+}, \mathrm{Rb}^{+}$and $\mathrm{Na}^{+}$, and $\mathrm{Cs}^{+}$ and $\mathrm{K}^{+}$(Vol'khin et al., 2008). Milyutin et al. (2009) studied the removal of micro-amounts of $\mathrm{Cs}^{+}$from brine solutions using ferrocyanide materials. They noticed that the distribution coefficient $\left(\mathrm{K}_{\mathrm{d}}\right)$ of ${ }^{137} \mathrm{Cs}$ was dependent on solution $\mathrm{pH}$ and the type of sorbent used. The results also showed that the $\mathrm{Cs}^{+}$adsorption significantly decreased at $\mathrm{pH}>11$ owing to the dissolution of the ferrocyanide component. Voronina and Semenishchev (2013) studied the effect of $\mathrm{K}^{+}, \mathrm{Na}^{+}$, and $\mathrm{NH}_{4}{ }^{+}$concentrations on the $\mathrm{Cs}^{+}$uptake onto ferrocyanide-modified titanium dioxide. They noticed that the prepared adsorbents were greatly specific to $\mathrm{Cs}^{+}$in the presence of $\mathrm{K}^{+}, \mathrm{Na}^{+}$, and $\mathrm{NH}_{4}{ }^{+}$. Most of the published articles in the literature studied the $\mathrm{Rb}^{+}$and $\mathrm{Cs}^{+}$adsorption from solutions comprising $\mathrm{Na}^{+}$ions. However, information on selective adsorption using ferrocyanides in the existence of other cations such as $\mathrm{K}^{+}$and $\mathrm{NH}_{4}{ }^{+}$ions is almost deficient. The $\mathrm{NH}_{4}{ }^{+}$affinity is highest for ferrocyanides (Voronina and Semenishchev, 2013).

It was also reported that $\mathrm{Rb}^{+}$and $\mathrm{Cs}^{+}$removal and recovery from the brine system was carried out using transition metal ferrocyanide adsorbents on a solid support such as ion-exchange resins, chitosan, zeolites, and silica gel (Egorin et al., 2014). Ni-K ferrocyanide supported on zirconium hydroxide is one of the best adsorbents that exhibited a high performance toward $\mathrm{Rb}^{+}$and $\mathrm{Cs}^{+}$removal. The stability of the solid support material is of importance to have potential adsorptionselective characteristics of the prepared adsorbent in the brine system (Egorin et al., 2014). However, silicic material used as supporting material is chemically unstable in alkali solutions, which could limit its use in metal removal and recovery. Our previous investigations of the adsorption characteristics of date pits will lead to develop modified material (s) for $\mathrm{Rb}^{+}$and $\mathrm{Cs}^{+}$adsorption, which would be used later for analytical purposes for removing $\mathrm{Rb}^{+}$and $\mathrm{Cs}^{+}$from the brine system. Date pits are stable in alkaline solutions, can be recommended as a support for a ferrocyanide sorbent. Metal fixation on adsorbent depends on various factors; namely its relative affinity (its speciation) and concentration. Petersková et al. (2012) studied the speciation of various metals such as $\mathrm{Li}^{+}, \mathrm{Rb}^{+}$, and $\mathrm{Cs}^{+}$. The speciation diagrams showed that these metals are mainly presented in brine as $\mathrm{M}^{+}$cations, and displayed a low affinity to form complexes with the anions.

\subsubsection{Imprinting polymers}

Recently, studies on the development of selective materials have been focused on imprinted polymers. Imprinting polymer (IPs) is a processed polymer using an imprinting methodology that creates selective recognition sites in the prepared polymer. It involves initiating the polymerization of monomers in the existence of the specific analyte (Haupt, 2001). They can function under harsh environmental conditions (Kala et al., 2004). IPs have been effectively investigated for selective metals extraction (Rao et al., 2004), organic molecules (Caro et al., 2003), chiral separation, and pre-concentration methodologies (Caro et al., 2006). Two pathways are identified for IP preparation; namely covalent and noncovalent (Haupt, 2001; Mosbach et al., 1996). The latter would be a more practical methodology for imita ting the interactions present in nature (Shea, 1994). Various key factors are needed for a successful IPs preparation, which are the monomer's ty pe, the crosslinkers, and the experimental conditions needed for a specific analyte (Abu-Surrah et al., 2009, 2010). The polymerization of polar acrylates-based IPs is ty pically accomplished via radical initiators. Recently, transition metal complex-based polymerization has also been developed (Abu-Surrah et al., 2007; Ibrahim et al., 2004; Ma tyjaszewski et al., 2001; Yliheikkilä et al., 2006). They can function with low metal-complex concentrations and under mild polymerization conditions (Abu-Surrah and Qaroush, 2007). In general, finding selec- tive, more efficient, and less expensive imprinted polymers for extraction/preconcentration of valuable ions is a vital and challenging task.

The rapid industrialization and technology revolution has greatly contributed to water pollution with toxic metals, such as cadmium, nickel, lead, mercury, etc. This fact poses serious negative impacts on the human habitat and aquatic organisms due to eco-toxicity effects (El-Taher et al., 2018; Jafari et al., 2018; Kobielska et al., 2018; Ting et al., 2017; Yi et al., 2017). Thus, there is the need to reduce toxic metal pollution, which often necessitates the adoption of common traditional methods of treatments, such as ion exchange (Martins et al., 2017), membrane separation (Rajewski et al., 2016), biological flocculation (Zhang et al., 2009), oxidation-reduction (Nguyen et al., 2017), chemical precipitation (Striebig, 2005) and adsorption (Yang et al., 2017). Out of them all, adsorption is the widely accepted and applied method because of some merits it has over others. These merits are simple to operate, cost-effective, and noticeable effect; but there are few demerits about this system too: regeneration of absorbability is poor, noticeable influence on the condition, and competing ions.

Most of the reviews on the ion imprinting technology (IIT) focus more on the ion imprinting polymer (IIP) and molecular imprinting technology (MIT) despite the fact that there is a scarcity of information on these two methods. Recently compiled literature from the year 2000 to early 2019 clearly showed that $6.3 \%$ of the results favored IIPs, while $10.3 \%$ of the searched results favored the MITs without any doubt more research or studies should focus on IIP compared to MIT (Chen et al., 2019).

IIT is the type of technology that establishes multiple actions within the site structure within a polymer matrix i.e. ion-imprinted polymer by the process of copolymerization functional monomer, as well as a crosslinker in the presence of target ion.

The target ion acts in the position of template molecules with an emphasis on coordination or electrostatic interactions. The template ion is disconnected from an acidic reagent. Thereafter, the template ions are formation occurred as a cross-linked polymer matrix. Ion imprinting technology is an integral part of MIT, frequently used in the detection, separation, and adsorption removal of toxic metals.

The application of IIPs technology is growing in removing many metal ions as they help to improve the recycling efficiency of these metals. Some of the applications of IIPs in metal removal are explained below. The comparison with other conventional metal recovery processes such as ion exchange and membrane separation is in vogue because of its advantages.

Copper $(\mathrm{Cu})$ is a potentially toxic metal and it usually makes up high concentrations of brine disposal from desalination plants. However, copper is also a vital mineral resource, hence the great need for its removal, as this would come with a plethora of financial and economic benefits. In a recent study (Yuan et al., 2015), a new kind of surface IIP was made using methacrylic acid (MAA), attapulgite, ethylene glycol dimethacrylate (EGDMA), 2-2, azobisisobutyronitrile (AIBN) as a functional monomer, support material, and initiator respectively to prepare $\mathrm{Cu}(\mathrm{II})$-IIP microgels. The outcome proved that the microgels had a high af finity for copper ions over magnesium and calcium ions. Another very recent study (Ren et al., 2018) made use of $\mathrm{Cu}(\mathrm{II})$ ion as the template and the adsorption capacity of $\mathrm{Cu}$ (II) was $39.82(\mathrm{mg} / \mathrm{g})$. Compared with conventional methods, which used solvent extraction wherein calcium ions competed in the selectivity (Fillipi et al., 1998).

Nickel (Ni) is also another major component of disposable brine and, thus, its removal is important. Moreover, just like copper, it has other industrial uses. Ni-IIP was prepared using a polyvinyl alcohol by combination of CTS, PVA, $\mathrm{Ni}$ (II) $\mathrm{Fe}_{3} \mathrm{O}_{4}$ to form beads. The nickel ions were imprinted on the beads and were gotten by the elution of Nickel from the CTS/PVA (Zhang et al., 2015). The adsorption capacity of the $\mathrm{Ni}$ (II) ions was $500.0(\mathrm{mg} / \mathrm{g})$ which is quite high compared to an earlier study that used the conventional method of electrocoagulation (Akbal et al., 2011). 
Table 7

Quantitative indicators of various brine treatment techniques.

\begin{tabular}{|c|c|c|c|}
\hline Technology & $\begin{array}{l}\text { Quan tita tive } \\
\text { Drivers }\end{array}$ & Quantitative Barriers & References \\
\hline RO & $\begin{array}{l}\text { Energy-efficient, } \\
\text { for seawater it } \\
\text { uses } 2 \mathrm{kWh} / \mathrm{m}^{3} \text { - } \\
6 \mathrm{kWh}_{\mathrm{e}} / \mathrm{m}^{3} \\
\text { product water; } \\
\text { for brackish } \\
\text { water: } 1.5 \\
\mathrm{kWh}_{\mathrm{e}} / \mathrm{m}^{3}-2.5 \\
\mathrm{kWh}_{\mathrm{e}} / \mathrm{m}^{3} \text { product } \\
\text { water }\end{array}$ & $\begin{array}{l}\text { Limited salinity range as } \\
\text { upper concentration is } \\
\text { ar ound } 75,000 \mathrm{mg} / \mathrm{L} \text {, the } \\
\text { unit cost is estima ted to } \\
\text { be } \$ 0.75 / \mathrm{m}^{3} \text { of } \\
\text { freshwater produced; } \\
\text { water recovery up to } 50 \% \\
\text { for feed brine with } \\
<70,000 \mathrm{mg} / \mathrm{L} \text { TDS and } \\
\text { up to } 10 \% \text { for feed brine } \\
\text { with } 85,000 \mathrm{mg} / \mathrm{L} \text { TDS }\end{array}$ & $\begin{array}{l}\text { Panagopoulos } \\
\text { et al. (2019); } \\
\text { Tong and } \\
\text { Elimelech } \\
\text { (2016); } \\
\text { Morillo et al. } \\
\text { (2014) }\end{array}$ \\
\hline FO & $\begin{array}{l}\text { Salinity limit > } \\
200,000 \mathrm{mg} / \mathrm{L} ; \\
\text { water recovery } \\
\text { up to } 98 \%\end{array}$ & $\begin{array}{l}0.8 \mathrm{kWh} / \mathrm{m}^{3}-21 \\
\mathrm{kWh} / \mathrm{m}^{3} \text { of feedwater } \\
\text { having sa linity of } \\
73,000 \mathrm{mg} / \mathrm{L} ; \text { costs } \\
\$ 0.63 / \mathrm{m}^{3} \text { of freshwater } \\
\text { produced }\end{array}$ & $\begin{array}{l}\text { Panagopoulos } \\
\text { et al. (2019); } \\
\text { Tong and } \\
\text { Elimelech } \\
\text { (2016); } \\
\text { Morillo et al. } \\
\text { (2014) }\end{array}$ \\
\hline $\mathrm{ED} / \mathrm{EDR}$ & $\begin{array}{l}\text { Water recovery } \\
86 \%-99 \%, \\
\text { salinity limit > } \\
100,000 \mathrm{mg} / \mathrm{L}\end{array}$ & $\begin{array}{l}\text { Energy use is } 7 \mathrm{kWh}_{\mathrm{e}} / \mathrm{m}^{3} \\
\text { - } 15 \mathrm{kWh} \mathrm{h}_{\mathrm{e}} / \mathrm{m}^{3} \text { of } \\
\text { concentrated brine from } \\
\text { RO; effluent with high } \\
\text { salinity }>10,000 \mathrm{mg} / \mathrm{L} \text {; } \\
\text { costs } \$ 0.85 / \mathrm{m}^{3} \text { of } \\
\text { freshwater produced }\end{array}$ & $\begin{array}{l}\text { Panagopoulos } \\
\text { et al. (2019); } \\
\text { Tong and } \\
\text { Elimelech } \\
\text { (2016); } \\
\text { Morillo et al. } \\
\text { (2014) }\end{array}$ \\
\hline MD & $\begin{array}{l}\text { TDS limit up to } \\
350,000 \mathrm{mg} / \mathrm{L} \\
\text { and water } \\
\text { recovery up to } \\
90 \%\end{array}$ & $\begin{array}{l}\text { Requir es } 22 \mathrm{kWh}_{\mathrm{e}} / \mathrm{m}^{3} \text { - } 67 \\
\mathrm{kWh} \\
\mathrm{e} / \mathrm{m}^{3} \text { of product } \\
\text { water; costs } \$ 1.17 / \mathrm{m}^{3} \text { of } \\
\text { freshwater produced }\end{array}$ & $\begin{array}{l}\text { Panagopoulos } \\
\text { et al. (2019); } \\
\text { Tong and } \\
\text { Elimelech } \\
\text { (2016); } \\
\text { Morillo et al. } \\
\text { (2014) }\end{array}$ \\
\hline $\begin{array}{l}\text { Brine } \\
\text { concentrator }\end{array}$ & $\begin{array}{l}\text { Salinity limit > } \\
250,000 \mathrm{mg} / \mathrm{L} \text {; } \\
\text { water recovery } \\
\text { up to } 98-99 \% \% \text {; } \\
\text { high qual ity } \\
\text { product water } \\
\text { with TDS } \\
<10 \mathrm{mg} / \mathrm{L}\end{array}$ & $\begin{array}{l}\text { Energy requirement of } 15 \\
\mathrm{kWh} / \mathrm{m}^{3}-70 \mathrm{kWh} / \mathrm{m}^{3} \text { of } \\
\text { feedwater; costs } \\
\$ 1.11-\$ 1.22 / \mathrm{m}^{3} \text { of } \\
\text { freshwater produced }\end{array}$ & $\begin{array}{l}\text { Panagopoulos } \\
\text { et al. (2019); } \\
\text { Tong and } \\
\text { Elimelech } \\
\text { (2016); } \\
\text { Morillo et al. } \\
\text { (2014) }\end{array}$ \\
\hline MSF & $\begin{array}{l}\text { Produce } \\
\text { freshwater with } \\
<10 \mathrm{mg} / \mathrm{L} \text { TDS; } \\
\text { water recovery } \\
\text { up to } 85 \%-90 \%\end{array}$ & $\begin{array}{l}\text { Energy consumption is } \\
12.5 \mathrm{kWh}_{\mathrm{e}} / \mathrm{m}^{3}-24 \\
\mathrm{kWh} / \mathrm{m}^{3}, \text { cost is } \\
\$ 1.40 . \mathrm{m}^{3}\end{array}$ & $\begin{array}{l}\text { Panagopoulos } \\
\text { et al. (2019); } \\
\text { Tong and } \\
\text { Elimelech } \\
\text { (2016); } \\
\text { Morillo et al. } \\
\text { (2014) }\end{array}$ \\
\hline MED & $\begin{array}{l}\text { Produce } \\
\text { freshwater with } \\
<10 \mathrm{mg} / \mathrm{L} \text { TDS; } \\
\text { water recovery } \\
\text { up to } 85 \%-90 \%\end{array}$ & $\begin{array}{l}\text { Energy required is } 7.7 \\
\mathrm{kWh}_{\mathrm{e}} / \mathrm{m}^{3}-21 \mathrm{kWh} / \mathrm{m}^{3} \text {, } \\
\text { cost is } \$ 1.10 . \mathrm{m}^{3}\end{array}$ & $\begin{array}{l}\text { Panagopoulos } \\
\text { et al. (2019); } \\
\text { Tong and } \\
\text { Elimelech } \\
\text { (2016); } \\
\text { Morillo et al. } \\
\text { (2014) }\end{array}$ \\
\hline WAIV & $\begin{array}{l}\text { produce final } \\
\text { brine with TDS }> \\
100,000 \mathrm{mg} / \mathrm{L} \\
\text { used to recover } \\
\text { mineral by- } \\
\text { products such as } \\
\text { ma gnesium salts; } \\
\text { lowest energy } \\
\text { consumption of } \\
0.3 \mathrm{kWh} / \mathrm{m}^{3}-1 \\
\mathrm{kWh}_{\mathrm{e}} / \mathrm{m}^{3}\end{array}$ & $\begin{array}{l}\text { Cost is around } \$ 1.37 / \mathrm{m}^{3} \\
\text { of freshwater evaporated, } \\
\text { no water recovery }\end{array}$ & $\begin{array}{l}\text { Panagopoulos } \\
\text { et al. (2019); } \\
\text { Tong and } \\
\text { Elimelech } \\
\text { (2016); } \\
\text { Morillo et al. } \\
\text { (2014) }\end{array}$ \\
\hline
\end{tabular}

The advantages of IIPs are quite promising as they have an edge over conventional methods including biological flocculation, membrane separation, adsorption, and chemical precipitation. The main advantages of IIPs include: a) easy use, b) regenerative ability that enables their multiple uses in removing metal ions, and c) high selectivity, which means they have good specific recognition; hence other metal ions, which are not intended to be removed, would compete for their active sites and good stability.

Despite the promising nature of IIPs, there still exist challenges with this technology. These include the method of preparation, which appears not to be fully developed. For instance, using a bulk polymerization method to prepare IIPs would damage the imprinted hole. The template cover is deeply embedded so it is not easily wa shed off. In solgel, method preparation the use of organic raw materials is toxic and quite expensive and in the use of in situ polymerization method, there is the use of the high-pressure column, which often, leads to poor binding ability and selectivity due to its slow flow rate. All these leads to low production of IIPs (J. Yang et al., 2018). Another challenge with IIPs is the absence of anionic polymers; hence, most of the IIPs are metal cations. This hinders IIPs from being used in removing anionic pollutants such as chlorides. Besides, there are only a few monomers used as the starting material, which are the alkenyl pyridines and imidazole. Employing the use of functional monomers needs to be developed to enable its wide usage.

\section{Best practices by utility companies and users}

Ta ble 5 represents the techno-economics evaluation of desalination brine treatment technologies and future prospects and an overview of the treatment technologies as it evaluates the technologies' ability to treat brine as well as their economic evaluation. Furthermore, Table 6 compares the production and operation conditions of different brine treatment technologies. Besides, as shown in Table 7 the main barrier for most of the used techniques are the energy requirements, which in turn increases the cost of the treatment method. Therefore, future research should focus on enhancing the disadvantages of the treatment techniques in which novel, low-cost and cost-effective materials could be used for the enhancement and sustainability of the ZLD system. Moreover, simulations of the process, techno-economic analysis as well as lifecycle assessments are required for the evaluation of the treatment technologies viability in various ZLD systems.

\section{Conclusion}

Pure potable water with high quality should certainly be produced to guarantee good human health when consumed. However, an adverse negative impact on the environment arises from the poor handling, manag ement, and reject brine disposal. Manag ement of brine is mandatory in order to preserve and conserve the environment, as well as protect the entire ecosystem in the long run. From this study, it was concluded that brine is best managed when reducing its volume to the bare and accepted levels, using an appropriate technology that supports ZLD. While the generated salts could be poured on land or wa ter, taking into consideration that the environmental impacts are greatly reduced. From all the reported studies in this paper, it can be concluded that all the emerging technologies are suitable for minimizing the brine volume. Various types of salts and metals are of economic value that can potentially generate profit when sold. The best brine management techniques are those that have the potential to combine several processes so that water is also recovered in addition to the substances. Lastly, the brine should be a resource and not a waste to at tain sustainability in its management approaches. Hybrid processes would be highly recommended to get the absolute transformation of the discarded brine from desalination processes to more valuable constituents. Advanced technologies in resource recovery and treatment of brine would need to utilize renewable energy from wind, solar radiation, or geothermal as power sources so that environmental degradation can drastically be reduced. Moreover, many researchers tend to underestimate the ecotoxic effects of brine disposal when conducting LCA analysis on desalination, simply because of the shortcomings associated with the current LCIA. This review article critically examined the two con- 
ventional approa ches commonly used in LCA, when evaluating the ecotoxic effect of discarded brine. These approaches have been simply identified as chemical-specific approaches, characterized by the inability to carry out complex composition analysis on complicated desalination effluents. The whole effluent is the completely effluent approach, though not required, to characterize the effluent, but only work with temporal estimation.

However, an improved approach called the "group-by-group" approach is able to evaluate the impact of more complex and variable seawa ter desalination concentrate. This ap proach takes collectively the advantages of the chemicals and the whole effluent, as earlier mentioned. It also rectifies their shortcomings and that is why it is considered the most suitable approach while conducting the analysis. Firstly, the "group-by-group" approach operates with less data to forecast the possible impact without compromising the reliability outcome significantly. It is able to cover the entire complex brine by providing comprehensive coverage. This approach not only focuses on the impacts of organic chemical and toxic or non-toxic metals but, also, equally considers the roles of inorganic chemicals that are known to be problematic when conducting impact assessment as a result of the unavailability of associated characterization factors. Presently, despite the facts that IIP possesses a very good reward, as far as its application in the metals recovery from brine is concerned, a lot of problems are still needed to be tackled simply because preparation mechanisms are yet to be fully matured, namely, metal ion-imprinted polymer is mainly settled within the cations and little research on metal anions (anionic polymers), in terms of productivity, the real production of the ion-imprinted is minimal, and the polymer selectivity should be high enough and strengthened, functional monomers should not only be limited to alkenyl pyridine and alkenyl imidazole. Additional monomers that are characterized by anionic coordination effects need to be developed to fulfill practical uses or needs.

\section{Declaration of competing interest}

The authors declare that they have no known competing financial interests or personal relationships that could have appeared to influence the work reported in this paper.

\section{Acknowledgement}

This work was made possible by Qatar University collaborative internal grant \# [QUCG-CAS-20/21-2]. The findings achieved herein are solely the responsibility of the author[s].

\section{References}

Abdul-Wahab, S., Al-Weshahi, M., 2009. Brine management: substituting chlorine with on-site produced sodium hypochlorite for environmentally improved desalination processes. Water Resour. Manag. 23 (12), 2437-2454.

Abu-Surrah, A.S., Ibra him, K.A., Abdel-Halim, H. M., 2009. Salicylaldim inatobased cobalt (III)-, iron (III)-, and chromi um (III)/methyl al uminoxane catalyst systems for polymerization of t-butyl acrylate. Transit. Met. Chem. 34 (7), $803-808$.

Abu-Surrah, A.S., Qa roush, A.K., 2007. Polymerization of vinyl monomers via MAO activated iron (II) dichloro complexes bearing bis (imino) pyridine-, quinol inal dimine-and thiophenal dimine-based tridentate nitrog en ligands. Eur. Polym. J. 43 (7), 2967-2974.

Abu-Surrah, A.S., Al-Degs, Y.S., 2010. A molecularly imprinted polymer via a salicylaldiminato-based cobalt (III) complex: a highly selective solid-phase extractant for anionic reactive dyes. J. Appl. Polym. Sci. 117 (4), 2316-2323.

Adham, S., Hussain, A., Matar, J.M., Dores, R., Janson, A., 2013. Application of membrane distillation for desalting brines from thermal desalination plants. Desalination 314, 101-108.

Afrasiabi, N., Shahbazali, E., 2011. RO brine treatment and disposal methods. Desalination and Water Treatment $35(1-3), 39-53$

Ahmed, M., Shayya, W.H., Hoey, D., Al-Handaly, J., 2001. Brine disposal from reverse osmosis desalination plants in Om an and the United Arab Emirates. Desalination 133 (2), 135-147.

Ahmed, M., Shayya, W.H., Hoey, D., Al-Handaly, J., 2002. Brine disposal from inland desalination plants: research needs as sess ment. Water Int. 27 (2),
194-201.

Ahuja, S., 2019. Global water challenges and solutions. Advances in Water Purification Techniques. Elsevier, pp. 17-39.

Akbal, F., Ca mc1, S., 2011. Copper, chromi um and nickel removal from metal plating wastewater by electrocoagulation. Desalination 269 (1-3), 214-222.

Al-Ghouti, M. A., Hawari, A., Khra isheh, M., 2013. A solid-phase extractant based on microemulsion modified date pits for toxic pollutants. J. Environ. Manag. $130,80-89$.

Al-Ghouti, M.A., Li, J., Salamh, Y., Al-Laqtah, N., Walker, G., Ahmad, M.N., 2010. Adsorption mechanisms of removing heavy metals and dyes from aqueous solution using date pits solid adsorbent. J. Hazard Mater. 176 (1-3), 510-520.

Al-Jaser, Z., Ha moda, M., 2019. Removal of nickel and vanadium from desalination brines by ion-exchange resins. Desalination and water treatment $157,148-156$.

Al-Mamun, A., Ahmad, W., Baawain, M.S., Khadem, M., Dhar, B.R., 2018. A review of microbial desalination cell technology: configurations, optimi zation and applications. J. Clean. Prod. 183, 458-480.

Al-Othman, A., Tawalbeh, M., Assa d, M.E.H., Alkayyali, T., Eisa, A., 2018. Novel multi-stag e flash (MSF) desalination plant driven by parabolic trough collectors and a solar pond: a simulation study in UAE. Desalination 443, 237-244.

Al Bazedi, G., Ettouney, R.S., Tewfik, S.R., Sorour, M.H., El-Rifai, M. A., 2014. Salt recovery from brine genera ted by larg e-scale seaw ater desalination plants. Desalination and Water Treatment 52 (25-27), 4689-4697.

Alkhudhiri, A., Darwish, N., Hilal, N., 2013. Produced water treatment: application of air gap membra ne distillation. Desalination 309, 46-51.

Amma, L., Ashraf, F., 2020. Brine management in reverse osmosis desalination: a UAE pers pective. In: 2020 Advances in Science and Engineering Technology International Conferences (ASET).

Ashoor, B., Mansour, S., Giwa, A., Dufour, V., Ha san, S., 2016. Principles and applications of direct contact membrane distillation (DCMD): a comprehensive review. Desalination 398, 222-246.

Assiry, A., 2011. Application of ohmic heating technique to approach near-ZLD during the evaporation process of seaw ater. Desalination 280 (1-3), 217-223.

Arroyo, F., Morillo, J., Usero, J., Rosa do, D., El Bakouri, H., 2019. Lithium recovery from desalination brines using specific ion-exchange resins. Desa lination 468, 114073.

Balasubram anian, P., 2013. A brief review on best av ailable technologies for reject water (brine) ma nagement in industries. Int. J. Environ. Sci. 3 (6), 2010-2018.

Bao, A., Zheng, H., Liu, Z., Huang, D., 2017. Adsorption behaviors of rubidium and cesium ions from aqueous solution onto sodium tetraphenylboratepoly acry lonitrile (TPB-PAN). Chemis try select 2, 11806-11814.

Beery, M., Repke, J.-U., 2010. Sustainability analysis of different SWRO pretreatment al ternatives. Desalination and Water Treatment 16 (1-3), 218-228.

Bell, E.A., Poynor, T.E., Newhart, K.B., Regnery, J., Coday, B.D., Ca th, T.Y., 2017. Produced water treatment using forward osmosis membranes: evaluation of extended-time performance and fouling. J. Membr. Sci. 525, 77-88.

Boillot, P., Peultier, J., 2014. Use of stainless steels in the industry: recent and future developments. Procedia Engineering 83, 309-321.

Boysen, R., 2018. Advances in the development of molecularly imprinted polymers for the separation and analys is of proteins with liquid chromatography. J. Separ. Sci. 42, 51-71.

Brancoli, P., Bolton, K., 2019. Life cycle as sess ment of waste ma nagement systems. Sustainable Reso urce Recovery And Zero Waste Approaches 23-33.

Breunig, H., Birkholzer, J., Borgia, A., Oldenburg, C., Price, P., McKone, T., 2013. Regional evaluation of brine management for geologic carbon sequestration. International Journal Of Greenhouse Gas Control 14, 39-48.

Burnett, D., 2011. Brine ma nagement: produced water and frac flowback brine. J. Petrol. Technol. 63 (10), 46-48.

Cama cho, L.M., Dumée, L., Zhang, J., Li, J.-d., Duke, M., Gomez, J., Gray, S., 2013. Advances in membrane distillation for water desalination and purification applications. Water 5 (1), 94-196.

Caro, D., 2019. Carbon footprint. Encyclopedia Of Ecology, pp. 252-257.

Caro, E., Marcé, R., Borr ull, F., Corm ack, P., Sherrington, D., 2006. Application of molecularly imprinted polymers to solid-phase extraction of compounds from environmental and biological samples. Trac. Trends Anal. Chem. 25 (2), $143-154$.

Ca ro, E., Marcé, R.M., Corm ack, P.A., Sherrington, D.C., Borr ull, F., 2003. Online solid-phas e extraction with molecularly imprinted polymers to selectively extract substituted 4-chlorophenols and 4-nitrophenol from water. J. Chroma togr. A 995 (1-2), 233-238.

Chancellor, C., Kirby, C., Elsharafi, M., 2016. In: Evaluate the Effect of pH on the Mixed Brine and Chemical Solutions, ume 6B. Energy.

Chen, H., Engkvist, O., Kogej, T., 2015. Compound properties and their influence on drug quality. The Practice of Medicinal Chemistry. Elsevier, pp. 379-393.

L. Chen J. Dai B. Hu J. Wang Y. Wu J. Dai ... Y. Yan Recent progress es on the adsorption and separation of ions by imprinting routes Separ. Purif. Rev. 2019129

Chen, S., Wang, M., Li, L., Guo, Y., 2017. Recovery of Rubidium and Cesium from Brines by Solvent Extraction. DEStech Transactions on Materials Science and Engineering.

Cheng, Z.L., Li, X., Chung, T.-S., 2018. The forward osmosis-pressure retarded osmosis (FO-PRO) hybrid system: a new process to mi tiga te membra ne fouling for sustainable osmotic power generation. J. Membr. Sci. 559, 63-74.

Chen, W., Lee, C., Chung, Y., Tien, K., Chen, Y., Chen, Y., 2020. Recovery of 
rabidium and cesium resources from brine of desalination through t-BAMBP extraction. Metals 10 (5), 607.

Chung, H., Nayar, K., Swam inathan, J., Chehay eb, K., Lienhard V, J., 2017 Thermodynamic analys is of brine management methods: zero-discharge desalination and salinity-gradient power production. Desalination 404, 291-303.

Chung, T.-S., Li, X., Ong, R.C., Ge, Q., Wang, H., Han, G., 2012a. Emerging forw ard osmosis (FO) technologies and challenges ahead for clean water and clean energy applications. Curr ent Opinion in Chemical Engineering 1 (3), 246-257.

Chung, T.-S., Zhang, S., Wang, K. Y., Su, J., Ling, M. M., 2012b. Forward osmosis processes: yesterday, today and tomorrow. Desalination 287, 78-81.

Cipollina, A., Micale, G., Rizzuti, L., 2011. A brine evaporative cooler/ concentrator for autonomous thermal desalination units. Desalination and Water Treatment 31 (1-3), 269-278.

Cobban, D., Ha nekom, D., Rusinga, F., 2011. Salt and water balance at the tutuka coal-fired power station, mpumal anga, South Africa and options for sustainable brine management. Proceedings of the 34th World Congress of the International Association for Hydro- Environment Research and Engineering: 33rd Hydrology and Water Resources Symposium and 10th Conference on Hydraulics in Water Engineering. pp. 1994-2005 Australia: Barton, A.C. T.: Engineers Australia. Retrieved from https://search.informit.com.au/ documentSumm ary.

Connor, R., 2015. The United Nations World Water Development Report 2015. In: Water for a Sustainable World, vol. 1. UNESCO publishing.

Darwish, M., Hass abou, A.H., Shom ar, B., 2013. Using Seaw ater Reverse Os mosis (SWRO) desalting system for less environmental impacts in Qatar. Desalination 309, 113-124.

Davenport, D., Deshmukh, A., Werber, J., Elimelech, M., 2018. High-pressure reverse osmosis for energy-efficient hypers al ine brine desalination: curr ent status, design considerations, and resear ch needs. Environ. Sci. Technol. Lett. 5 (8), $467-475$.

Dawoud, M. A., 2012. Environmental impacts of seawater desalination: arabian Gulf case study. Int. J. Environ. Sustain. 1 (3).

De Buren, L., Sharbat, A., 2015. Inland Desalination and Brine Management: Salt Recovery and Beneficial Uses of Brine. World Environmental And Water Reso urces Congress 2015.

Delgado, G.G., 2009. Treatment of RO Concentrate Using VSEP Technology.

Desai, D., Beh, E., Sa hu, S., Vedhar athinam, V., van Overmeere, Q., de Lannoy, C., et al., 2018. Electrochemical desalination of seaw ater and hypersal ine brines with coupled electricity storage. ACS Energy Letters 3 (2), 375-379.

Diallo, M., Kotte, M., Cho, M., 2015. Mining critical metals and elements from seaw ater: opportunities and chal lenges. Environ. Sci. Technol. 49 (15), 9390-9399.

Dindi, A., Quang, D., AlNashef, I., Abu-Zahra, M., 2018. A process for combined CO 2 utilization and treatment of desalination reject brine. Desalination 442, $62-74$.

Dong, H., Yang, E., Unluer, C., Jin, F., Al-Tabbaa, A., 2018. Investigation of the properties of $\mathrm{MgO}$ recovered from reject brine obtained from desalination plants. J. Clean. Prod. 196, 100-108.

Dow, N., Zhang, J., Duke, M., Li, J.-d., Gray, S.R., Ostarcevic, E., 2008. Membra ne Distillation of Brine Wastes.

Drobek, M., Ya cou, C., Motuzas, J., Julbe, A., Ding, L., da Costa, J.C.D., 2012. Long term pervaporation desalination of tubular MFI zeolite membranes. J. Membr. Sci. 415, 816-823.

Egorin, A., Didenko, N., Ka idalova, T., Zemskova, L., 2014. Preparation and properties of chitosan-containing ferrocyanide sorbents for the sorption of 137 Cs from liquid media. Radiochemistry 56 (3), 275-282.

Einav, R., Harussi, K., Perry, D., 2003. The footprint of the desalination processes on the environment. Desalination 152 (1-3), 141-154.

Elcik, H., Fortunato, L., Alpatova, A., Soukane, S., Orfi, J., Ali, E., et al., 2020 Multi-effect distillation brine treatment by membra ne distillation: effect of antiscalant and antifoam ing ag ents on membra ne performa nce and scaling control. Desalination 493, 114653.

El-Naas, M., Mohammad, A., Suleiman, M., Al Musharfy, M., Al-Marzouqi, A., 2017. A new process for the capture of $\mathrm{CO} 2$ and reduction of water salinity. Desalination 411, 69-75.

El-Taher, A., Zakaly, H. M., Elsaman, R., 2018. Environmental implications and spatial distribution of natural radionuclides and heavy metals in sediments from four harbours in the Egyptian Red Sea coast. Appl. Radiat. Isot. 131, $13-22$.

Elsaid, K., Sayed, E., Abdelkar eem, M., Baroutaji, A., Olabi, A., 2020. Environmental impact of desalination processes: mitigation and control strategies. Sci. Total Environ. 740, 140125.

Elsayed, M.L., Mesalhy, O., Mohamm ed, R. H., Chow, L.C., 2018. Effect of disturbances on MED-TVC plant characteristics: dynamic modeling and simulation. Desalination 443, 99-109.

Fath, H., Sadik, A., Mezher, T., 2013. Present and future trend in the production and energy consumption of desalinated water in GCC countries. Int. J. Therm. Environ. Eng 5 (2), 155-165.

Ferry, J., Widyolar, B., Jiang, L., Winston, R., 2020. Solar thermal wastewater evaporation for brine management and low pressure steam using the XCPC. Appl. Energy 265, 114746

Fillipi, B.R., Scam ehorn, J.F., Christian, S.D., Taylor, R.W., 1998. A comparative economic analysis of copper removal from water by ligand-modified micellarenhanced ultrafiltration and by conventional solvent extraction. J. Membr. Sci.
145 (1), 27-44.

Forr estal, C., Xu, P., Jenkins, P.E., Ren, Z., 2012. Microbial desalination cell with capacitive adsorption for ion migration control. Bioresour. Technol. 120, 332-336.

Ghys elbrecht, K., Van Houtte, E., Pinoy, L., Verbauwhede, J., Van der Bruggen, B., Meesschaert, B., 2012. Treatment of RO concentrate by means of a combination of a willow field and electrodialysis. Resour. Conserv. Recycl. 65, 116-123.

Gilron, J., Folkman, Y., Savliev, R., Waisman, M., Kedem, O., 2003. WAIV-wind aided intensified evaporation for reduction of desalination brine volume. Desalination 158 (1-3), 205-214.

Gilron, J., Ramon, E., Assaf, N., Kedem, O., 2019. Wind-aided intensified evaporation (WAIV): an environmentally sustainable method for brine ma nagement. Current Trends and Future Developments on (Bio-) Membranes. Elsevier, pp. 215-241.

Giwa, A., Dufour, V., Al Marzooqi, F., Al Ka abi, M., Hasan, S., 2017. Brine ma nagement methods: recent innovations and curr ent status. Desalination 407, 1-23.

Giwa, A., Fath, H., Hasan, S.W., 2016. Humidification-dehumidification desalination process driven by photovoltaic thermal energy recovery (PV$\mathrm{HDH}$ ) for small-scale sustainable water and power production. Desalination 377, 163-171.

Gong, H., Anastasio, D.D., Wang, K., McCutcheon, J.R., 2017. Finding better draw solutes for osmotic heat engines: understanding transport of ions during pressure retarded osmosis. Desalination 421, 32-39.

Gorjian, S., Jams hidian, F., Hoss einqolilou, B., 2019. Feasible solar applications for brines disposal in desalination plants. Solar Desalination Technology $25-48$.

Gude, G., 2018. Emerging Technologies for Sustainable Desalination Handbook. Butterworth-Heinemann.

Guerra, D.L., Batista, A.C., Viana, R.R., Airoldi, C., 2011. Adsorption of rubidium on raw and MTZ-and MBI-imogolite hybrid surfaces: an evidence of the chelate effect. Desalination 275 (1-3), 107-117.

Guo, Z., Ji, Z., Chen, Q., Liu, J., Zhao, Y., Li, F., Liu, Z., Yuan, J., 2018. Prefractionation of $\mathrm{LiCl}$ from concentrated seawater/salt lake brines by electrodialysis with monovalent selective ion exchange membra nes. J. Clean. Prod. 193, 338-350.

Gurung, M., Adhikari, B.B., Alam, S., Ka wakita, H., Ohto, K., Inoue, K., Ha ra da, H., 2013. Adsorptive removal of Cs (I) from aqueous solution using poly phenols enriched biom as s-based adsorbents. Chem. Eng. J. 231, 113-120.

Hajbi, F., Ha mm i, H., M'nif, A., 2010. Reuse of RO desalination plant reject brine. J. Phas e Equilibria Diffus. 31 (4), 341-347.

Ha rdoy, J.E., Mitlin, D., Satterthwaite, D., 2013. Environmental Problems in an Urbanizing World: Finding Solutions in Cities in Africa, Asia and Latin America. Routledge.

Ha upt, K., 2001. Molecularly imprinted polymers in analytical chemistry. Analyst 126 (6), 747-756

He, C., Carpenter, G., Westerhoff, P., 2013. Demonstrating and innova tive combination of ion exchange pretreatment and electrodialysis reversal for reclaimed water reverse osmosis concentrate minimization, final report. Final Report, Water Reuse Research Foundation.

A.D. Henderson M. Z. Ha uschild D. van de Meent M. A. Huijbregts H. F. Larsen M. Marg ni ... O. Jolliet USEtox fate and ecotoxicity factors for comparative as sess ment of toxic emissions in life cycle analysis: sensitivity to key chemical properties Int. J. Life Cycle Assess. 1682011701

Ho over, L.A., Phillip, W.A., Tira ferri, A., Yip, N.Y., Elimelech, M., 2011. Forward with osmosis: emerging applications for greater sustainability. ACS Publications.

Huo, X., Vanneste, J., Cath, T., Strathmann, T., 2020. A hybrid catalytic hydrogenation/membrane distillation process for nitrogen resource recovery from nitrate-contam inated waste ion exchange brine. Water Res. 175, 115688.

Huth, E., Muthu, S., Ruff, L., Brant, J.A., 2014. Feasibility as sess ment of pervaporation for desalinating high-salinity brines. Journal of Water Reuse and Desalination 4 (2), 109-124.

Ibra him, K., Yliheikkilä, K., Abu-Surr ah, A., Löfgren, B., Lappalainen, K., Leskelä, M., Seppälä, J., 2004. Polymerization of methyl methacrylate in the presence of iron (II) complex with tetradentate nitrogen ligands under conditions of atom transfer radical polymerization. Eur. Polym. J. 40 (6), 1095-1104.

Jafari, A., Ka ma rehie, B., Ghaderpoori, M., Khoshnam vand, N., Birjandi, M., 2018. The concentration data of heavy metals in Iranian grown and imported rice and human heal th hazard as sessment. Data in brief 16, 453-459.

Jalilian, R., Shahmari, M., Taheri, A., Gholami, K., 2019. Ultras onic-as sisted micro solid phase extraction of arsenic on a new ion-imprinted polymer synthesized from chitosan-stabilized pickering emulsion in water, rice and vegetable samples. Ultras onics sonochemistry, 104802.

Jeppesen, T., Shu, L., Keir, G., Jega theesan, V., 2009. Metal recovery from reverse osmosis concentrate. J. Clean. Prod. 17 (7), 703-707.

Ji, X., Curcio, E., Al Obaidani, S., Di Profio, G., Fontananova, E., Drioli, E., 2010. Membra ne distillation-crystallization of seaw ater reverse osmosis brines. Separ. Purif. Technol. 71 (1), 76-82.

Jiang, C., Wang, Y., Zhang, Z., Xu, T., 2014. Electrodialy sis of concentrated brine from RO plant to produce coarse salt and freshwater. J. Membr. Sci. 450, 323-330.

Kala, R., Gladis, J.M., Rao, T.P., 2004. Preconcentrative separation of erbium from Y, Dy, Ho, Tb and Tm by using ion imprinted polymer particles via solid phas e extraction. Anal. Chim. Acta 518 (1-2), 143-150. 
Katal, R., Ying Shen, T., Jafari, I., Masudy-Panah, S., Hoss ein Davood Abadi Farahani, M., 2020. An Overview on the Treatment and Management of the Desalination Brine Solution. Desalination - Challenges and Opportunities.

Ka tzir, L., Volkma nn, Y., Daltrophe, N., Korngold, E., Mesalem, R., Or en, Y., Gilron, J., 2010. WAIV-Wind aided intensified evaporation for brine volume reduction and generating mineral byproducts. Desalination and Water Treatment 13 (1-3), 63-73.

Kayo, C., Tojo, S., Lwaoka, M., Ma tsumoto, T., 2014. Evaluation of biom as s production and utilization systems. Research Approaches to Sustainable Biomas s Systems 309-346.

Kazner, C., Jamil, S., Phuntsho, S., Shon, H., Wintgens, T., Vigneswaran, S., 2014. Forward osmosis for the treatment of reverse osmosis concentrate from water reclam ation: process performance and fouling control. Water Sci. Technol. 69 (12), 2431-2437.

Khajeh, M., Heidari, Z.S., Sanchooli, E., 2011. Synthesis, char acterization and removal of lead from water samples using lead-ion imprinted polymer. Chem. Eng. J. 166 (3), 1158-1163.

Khoshrou, I., Nasr, M.J., Bakhtari, K., 2017. New opportunities in ma ss and energy consumption of the Multi-Stage Flash Distillation type of brackish water desalination process. Sol. Energy 153, 115-125.

Klon, A.E., Glick, M., Davies, J.W., 2004. Application of ma chine learning to improve the results of high-throughput docking ag ainst the HIV-1 protease. J. Chem. Inf. Comput. Sci. 44 (6), 2216-2224.

Kobielska, P.A., Howarth, A.J., Farha, O.K., Nayak, S., 2018. Metal-organic fram eworks for heavy metal removal from water. Coord. Chem. Rev. 358, 92-107.

Korngold, E., Aronov, L., Daltrophe, N., 2009. Electrodialysis of brine solutions discharged from an RO plant. Desalination 242 (1-3), 215-227.

Kumar, A., Balouch, A., Pathan, A.A., 2019. Synthesis, adsorption and analytical applicability of Ni-im printed polymer for selective adsorption of $\mathrm{Ni2}+$ ions from the aqueous environment. Polym. Test.

Kylili, A., Seduikyte, L., Fokaides, P., 2018. Life cycle analys is of poly urethane foam wastes. Recycling Of Polyurethane Foam s 97-113.

Lars en, H.F., 2018. LCA of wastewater treatment. Life Cycle Assess ment. Springer, pp. 861-886.

Lattemann, S., Höpner, T., 2008. Environmental impact and im pact as sess ment of seawater desalination. Desalination 220 (1-3), 1-15.

Le Dirach, J., Nisan, S., Poletiko, C., 2005. Extraction of strategic materials from the concentrated brine rejected by integrated nuclear desalination systems. Desalination $182(1-3), 449-460$.

Lee, S., Boo, C., Elimelech, M., Hong, S., 2010. Comparis on of fouling behavior in forw ard osmosis (FO) and reverse osmosis (RO). J. Membr. Sci. 365 (1-2) 34-39.

Li, W., Krantz, W., Cornelissen, E., Post, J., Verliefde, A., Tang, C., 2013. A novel hybrid process of reverse electrodialysis and reverse osmosis for low energy seawater desalination and brine ma nagement. Appl. Energy 104, 592-602.

Li, Y., Styczynski, J., Huang, Y., Xu, Z., McCutcheon, J., Li, B., 2017. Energypositive wastewater treatment and desalination in an integrated microbial desalination cell (MDC)-microbial electrolysis cell (MEC). J. Power Sources 356, 529-538.

Li, Z., Pranolo, Y., Zhu, Z., Cheng, C., 2017. Solvent extraction of cesium and rubidium from brine solutions using 4-tert-butyl-2-( $\alpha$-methylbenzyl)-phenol. Hy drom etally rg y 171, 1-7.

Lima, A.N., Philot, E.A., Trossini, G.H.G., Scott, L.P.B., Maltarollo, V.G., Honorio, K. M., 2016. Use of machine learning approaches for novel drug discovery. Expet Opin. Drug Discov. 11 (3), 225-239.

Lins, S.S., Virgens, C.F., dos Santos, W.N.L., Estevam, I.H.S., Brandão, G.C., Felix, C.S.A., Ferreira, S. L.C., 2019. On-line solid phase extraction system using an ion imprinted polymer based on dithizone chelating for selective preconcentration and determ ination of mercury (II) in natural waters by CV AFS. Microchem. J. 150, 104075.

Liu, S., Liu, H., Huang, Y., Yang, W., 2015. Solvent extraction of rubidium and cesium from salt lake brine with t-BAMBP-kerosene solution. Trans. Nonferrous Metals Soc. China 25, 329-334.

Loeb, S., Van Hessen, F., Levi, J., Ventura, M., 1976. The Os motic Power Plant. Paper Presented at the 11th Inters ociety Energy Conversion Engineering Conference.

Loganathan, P., Naidu, G., Vigneswaran, S., 2017. Mining valuable minerals from seaw ater: a critical review. 1. Water resear ch \& technology.

Lozier, J.C., Erdal, U., Lynch, A., Schindler, S., 2007. Evaluating Traditional and Innovative Concentrate Treatment and Disposal Methods for Water Recycling at Big Bear Valley. CH 2M HILL report, California.

Luo, H., Xu, P., Jenkins, P.E., Ren, Z., 2012. Ionic composition and transport mechanisms in mi crobial desalination cells. J. Membr. Sci. 409, 16-23.

Luo, Y., Chen, Q., Shen, X., 2019. Complexation and extraction investigation of rubidium ion by calixcrown- $\mathrm{C}_{2} \mathrm{mi}_{\mathrm{mNTF}}$ sy stem. Separ. Purif. Technol. 227, 115704.

E. Lyons P. Zhang T. Benn F. Shar if K. Li J. Crittenden ... Y. Chen Life cycle as sessment of three water supply systems: im portation, reclam ation and desalination Water Sci. Technol. Water Supply 942009439448

Ly, L., Ferg us, I., Page, S., 2013. CSG water: desalination and the challenge for the CS G industry - developing a holistic CS G brine management solution. The APPEA Journal 53 (1), 193.

Mabrouk, A.N., Fath, H.E., 2015. Technoeconomic study of a novel integrated thermal MSF-MED desalination technology. Desalination 371, 115-125.

Ma cedonio, F., Katzir, L., Geisma, N., Simone, S., Drioli, E., Gilron, J., 2011.
Wind-Aided Intensified eVaporation (WAIV) and Membra ne Crystallizer (MCr) integrated brackish water desalination process: advantages and drawbacks. Desalination 273 (1), 127-135.

Mansour, S., Arafat, H., Hasan, S., 2017. Brine ma nagement in desalination plants. Desa lination Sustainability 207-236.

Manzoor, K., Khan, S., Jamal, Y., Shahzad, M., 2017. Heat extraction and brine management from salinity gradient solar pond and membra ne distillation. Chem. Eng. Res. Des. 118, 226-237.

Martinetti, C.R., Childress, A.E., Ca th, T.Y., 2009. High recovery of concentrated RO brines using forward osmosis and membrane distillation. J. Membr. Sci. $331(1-2), 31-39$.

Martins, P.J., Reis, P.M., Martins, R.C., Gando-Ferr eira, L. M., Quinta-Ferr eira, R. M., 2017. Iron recovery from the Fenton's treatment of winery effluent using an ion-exchange resin. J. Mol. Liq. 242, 505-511.

Matyja szewski, K., Xia, J., 2001. Atom transfer radical polymerization. Chem. Rev. 101 (9), 2921-2990.

Mavukkandy, M. O., Chabib, C. M., Mustafa, I., Al Ghaferi, A., AlMarzooqi, F., 2019. Brine management in desalination industry: from waste to resources generation. Desalination 472, 114187.

McCutcheon, J.R., Elimelech, M., 2006. Influence of concentrative and dilutive internal concentration polarization on flux behavior in forward osmosis. J. Membr. Sci. 284 (1-2), 237-247.

McCutcheon, J.R., McGinnis, R.L., Elimelech, M., 2006. Desalination by am monia-carbon dioxide forward osmosis: influence of draw and feed solution concentrations on process performance. J. Membr. Sci. 278 (1-2), 114-123.

McGinnis, R. L., Elimelech, M., 2007. Energy requirements of ammonia-carbon dioxide forward osmosis desalination. Desalination 207 (1-3), 370-382.

McGinnis, R.L., Elimelech, M., 2008. Global challenges in energy and water supply: the promise of engineered osmosis. ACS Publications.

Meneses, M., Pasqualino, J.C., Castells, F., 2010. Environmental as sessment of urban wastewater reuse: treatment al ternatives and applications. Chemosphere 81 (2), 266-272.

Mercer, J., 2015. Microbial fuel cells: genera ting power from waste. Rev. Eng. Everyday Life.

Milyutin, V., Mikheev, S., Gelis, V., Kozlitin, E., 2009. Sorption of cesium on ferrocyanide sorbents from highly saline solutions. Radiochemistry 51 (3), 298-300.

Mohapatra, P., Siebel, M., Gijzen, H., Van der Hoek, J., Groot, C., 2002. Improving eco-efficiency of Amsterdam water supply: a LCA approach. J. Water Supply Res. Technol. - Aqua 51 (4), 217-227.

Morillo, J., Usero, J., Rosa do, D., El Bakouri, H., Riaza, A., Bernaola, F. -J., 2014 Comparative study of brine management technologies for desalination plants. Desa lination 336, 32-49.

Mosbach, K., Ramström, O., 1996. The emerging technique of molecular imprinting and its future impact on biotechnology. Biotechnology 14 (2), 163.

Muñoz, I., Milà-i-Canals, L., Fernández-Alba, A.R., 2010. Life cycle as sess ment of water supply plans in Mediterranean Spain: the Ebro river transfer vers us the AGUA Programme. J. Ind. Ecol. 14 (6), 902-918.

Mustafa, J., Mourad, A., Al-Marzougi, A., El-Naas, M., 2020. Simultaneous treatment of reject brine and capture of carbon dioxide: a comprehensive review. Desa lination 483, 114386.

Naidu, G., Jeong, S., Johir, M., Fane, A., Kandas amy, J., Vigneswara n, S., 2017. Rubidium extraction from seawater brine by an integrated membrane distillation-selective sorption system. Water Res. 123, 321-331.

Neilly, A., Jega theesan, V., Shu, L., 2009. Evaluating the potential for zero discharg e from reverse osmosis desalination using integrated processes-A review. Desalination and Water Treatment 11 (1-3), 58-65.

Nguyen, T., Montemor, M.F., 2017. Redox active materials for metal compound based hybrid electrochemical energy storag e: a pers pective view. Appl. Surf. Sci. $422,492-497$.

Norm an, R.S., 1974. Water salination: a source of energy. Science 186 (4161), $350-352$.

Y. Oren E. Korngold N. Daltrophe R. Messalem Y. Volkman L. Aronov ... J. Gilr on Pilot studies on high recovery BWRO-EDR for near zero liquid discharge approach Desalination 26132010321330

Pakade, V., Cukrowska, E., Darkwa, J., Torto, N., Chimuka, L., 2011. Selective removal of chromium (VI) from sulphates and other metal anions using an ionim printed polymer. WaterS A 37 (4), 529-538.

Panagopoulos, A., Ha ra la mbous, K.-J., Loizidou, M., 2019. Desalination brine disposal methods and treatment technologies-A review. Science of the Total Environment.

Pehnt, M., 2006. Dynamic life cycle as sess ment (LCA) of renewable energy technologies. Renew. Energy 31 (1), 55-71.

J. Peng W. Gao B.K. Gupta Z. Liu R. Romero-Aburto L. Ge ... G. Gao Graphene quantum dots derived from carbon fibers Nano Lett. 1222012844849

Petala, M., Zouboulis, A., 2006. Vibratory shear enhanced processing membrane filtration applied for the removal of natural organic matter from surface waters, J. Membr. Sci. 269 (1-2), 1-14.

Peters en, K. L., Frank, H., Paytan, A., Bar-Zeev, E., 2018. Impacts of seawater desalination on coas tal environments. Sustainable Desalination Ha ndbook. Elsevier, pp. 437-463.

Peters ková, M., Valderra ma, C., Gibert, O., Cortina, J.L., 2012. Extraction of valuable metal ions ( $\mathrm{Cs}, \mathrm{Rb}, \mathrm{Li}, \mathrm{U})$ from reverse osmosis concentrate using selective sorbents. Desalination 286, 316-323.

Pram anik, B., Shu, L., Jega theesan, V., 2017. A review on the ma nagement and 
treatment of brine solutions. Environmental science: water research \& technology 3 (4), 625-658.

Quiñones-Bolaños, E., Zhou, H., Parkin, G., 2005. Membra ne pervaporation for wastewater reuse in mi croirrig ation. J. Environ. Eng. 131 (12), 1633-1643.

Qu, J., Escobar, L., Li, J., Rao, Z., Xu, B., 2020. Experimental study of evaporation and crystallization of brine droplets under different temperatures and humidity levels. Int. Comm un. Heat Mass Tran. 110, 104427.

Rahman, S. M., Eckelm an, M.J., Onnis-Hayden, A., Gu, A.Z., 2018. Comparative life cycle as sess ment of advanced wastewater treatment processes for removal of chemicals of emerging concern. Environ. Sci. Technol. 52 (19), 11346-11358.

Rajewski, J., Religa, P., 2016. Synerg is tic extraction and separation of chromium (III) from acidic solution with a double-carr ier supported liquid membrane. J. Mol. Liq. 218, 309-315.

Raluy, R., Serra, L., Uche, J., 2005. Life cycle as sessment of desalination technologies integrated with renewable energies. Desalination 183 (1-3), 81-93.

Ramon, G.Z., Feinberg, B.J., Hoek, E.M., 2011. Membrane-based production of salinity-gradient power. Energy Environ. Sci. 4 (11), 4423-4434.

Rao, T.P., Daniel, S., Gladis, J.M., 2004. Tailored ma terials for preconcentration or separation of metals by ion-imprinted polymers for solid-phase extraction (IIP-SPE). Trac. Trends Anal. Chem. 23 (1), 28-35.

Rebitzer, G., Ekvall, T., Frischknecht, R., Hunkeler, D., Norr is, G., Rydberg, T., Pennington, D.W., 2004. Life cycle as sess ment: Part 1: fram ework, goal and scope definition, inventory analysis, and applications. Environ. Int. 30 (5), 701-720.

Ren, Z., Zhu, X., Du, J., Kong, D., Wang, N., Wang, Z., Zhou, Z., 2018. Facile and green preparation of novel adsorption ma terials by combining sol-gel with ion imprinting technology for selective removal of $\mathrm{Cu}$ (II) ions from aqueous solution. Appl. Surf. Sci. 435, 574-584.

Ripin, N.H.M., Goh, P.S., Lau, W.J., Isma il, A.F., Ng, B.C., 2019. Pressureretarded osmosis. Membra ne Separation Principles and Applications. Elsevier, pp. 339-359.

Rodriguez-Rojas, F., López-Marras, A., Celis-Plá, P., Muñoz, P., GarcíaBartolomei, E., Valenzuela, F., et al., 2020. Ecophysiological and cellular stress responses in the cosmopolitan brown macroalga Ectocarpus as biom onitoring tools for as sessing desalination brine impacts. Desalination 489, 114527. https://doi. or g/10.1016/j. desal. 2020.114527.

Rodríguez-DeLa Nuez, F., Franquiz-Suárez, N., Santiago, D.E., Veza, J.M., Sadhwani, J.J., 2012. Reuse and minimization of desalination brines: a review of al ternatives. Desalination and Water Treatment 39 (1-3), 137-148.

Sa dhwani, J.J., Veza, J.M., Santana, C., 2005. Ca se studies on environmental im pact of seawater desalination. Desalination 185 (1-3), 1-8.

Sa eed, H. M., Huss eini, G.A., Yousef, S., Saif, J., Al-Asheh, S., Fara, A.A., Azzam, S., Khawaga, R., Aidan, A., 2015. Microbial desalination cell technology: a review and a case study. Desalination 359, 1-13.

Sakr, M., Liu, S., 2014. A comprehensive review on applications of ohmic heating $(\mathrm{OH})$. Renew. Sustain. Energy Rev. 39, 262-269.

Salih, H., Li, J., Kaplan, R., Dastgheib, S., 2017. Life cycle as sess ment of treatment and handling options for a highly saline brine extracted from a potential CO 2 storage site. Water Res. 122, 419-430.

Shatat, M., Riffat, S.B., 2014. Water desalination technologies utilizing conventional and renewable energy sources. Int. J. Low Carbon Technol. 9 (1), $1-19$.

Shahmansouri, A., Min, J., Jin, L., Bellona, C., 2015. Feasibility of extraction valuable minerals from desalination concentrate: a comprehensive litera ture review. J. Clean. Prod. 100, 4-16.

Shea, K. J., 1994. Molecular im printing of synthetic network polymers: the de novo synthesis of ma cromolecular binding and cataly tic sites. Trends Polym. Sci. 2, 166-173.

Shi, W., Benjam in, M. M., 2011. Effect of shear rate on fouling in a vibratory shear enhanced processing (VSEP) RO system. J. Membr. Sci. 366 (1-2), 148-157.

Singh, D., Sirkar, K. K., 2012. Desalination of brine and produced water by direct contact membrane distillation at high temperatures and pressures. J. Membr. Sci. 389, 380-388.

Smith, D.A., 2010. Metabolism, Pharma cokinetics and Toxicity of Functional Groups: Impact of Chemical Building Blocks on ADMET. Royal Society of Chemistry.

Stacklin, C., 2012. Innovative brine management modeling: as sess ment of im pacts to water reuse and POTW's. Proceedings Of The Water Environment Federation 5214-5237 2012(10).

Stokes, J.R., Horvath, A., 2009. Energy and air emission effects of water supply. ACS Publications.

Striebig, B.A., 2005. Chemical precipitation. Water Encyclopedia 4, 586-589.

Subram ani, A., DeCa rolis, J., Pearce, W., Jacangelo, J.G., 2012. Vibratory shear enhanced process (VSEP) for treating brackish water reverse osmosis concentrate with high silica content. Desalination 291, 15-22.

Subram ani, A., Jacangelo, J.G., 2014. Treatment technologies for revers e osmosis concentrate volume minimization: a review. Separ. Purif. Technol. 122, $472-489$.

Subramani, A., Jacangelo, J.G., 2015. Emerging desalination technologies for water treatment: a critical review. Water Res. 75, 164-187.

Subram ani, A., Schlicher, R., Long, J., Yu, J., Lehman, S., Jacangelo, J.G., 2011. Recovery optimization of membrane processes for treatment of produced water with high silica content. Desalination and Water Treatment 36 (1-3), 297-309.

Suresh, K., Dillibabu, R., 2018. Designing a ma chine learning based software risk as sess ment model using Naïve Bayes al gori thm. TAGA J 14, 3141-3147.

Tang, W., Ng, H. Y., 2008. Concentration of brine by forward osmosis: performance and influence of membrane structure. Desalination 224 (1-3), $143-153$.

Ting, Y., Huang, H.-j., Lai, F.-y., 2017. Pollution hazards of heavy metals in sewage sludge from four wastewater treatment plants in Nanchang, China Trans. Nonferrous Metals Soc. China 27 (10), 2249-2259.

Tong, T., Elimelech, M., 2016. The global rise of zero liquid discharge for wastewater ma nagement: drivers, technologies, and future directions. Environ. Sci. Technol. 50, 6846-6855.

Tow, E.W., McGovern, R. K., 2015. Raising forward osmosis brine concentration efficiency through flow rate optimization. Desalination 366, 71-79.

Tran, A.T., Zhang, Y., Jullok, N., Meesschaert, B., Pinoy, L., Van der Bruggen, B., 2012. RO concentrate treatment by a hybrid system consisting of a pellet reactor and electrodialysis. Chem. Eng. Sci. 79, 228-238.

Vince, F., Aoustin, E., Bréant, P., Leparc, J., 2009. A Life-Cycle Based Tool for the Environmental Footprinting of Potable Water Production.

Vince, F., Aoustin, E., Bréant, P., Marechal, F., 2008. LCA tool for the environmental evaluation of potable water production. Desalination 220 (1-3), $37-56$.

Vol'khin, V., Glushankova, I., Kolesova, S., Shul'ga, E., 2008. Sorption recovery of rubidium ions from highly mineralized solutions to obtain rubidium chloride of reag ent grade. Russ. J. Appl. Chem. 81 (7), 1140-1143.

Voronina, A., Semenishchev, V., 2013. Influence of the concentrations of potassium, sodium, and ammonium ions on the cesium sorption with mixed nickel potassium ferrocyanide sorbent based on hydrated titanium dioxide. Radiochemistry 55 (4), 399-403.

Wiechert, A., Ladshaw, A., Gill, G., Wood, J., Yiacoumi, S., Tsouris, C., 2018. Uranium resource recovery from desalination plant feed and reject water using am idoxime functionlized adsorbent. Ind. Eng. Chem. Res. 57, 17237-17244.

Wu, C., Chang, C., Li, Y., Lin, P., 2018. Feasibility study for the production of multi-oxidants from the desalination of seawater brine. Water Quality Research Journal 54 (3), 242-248.

Xevg enos, D., Moustakas, K., Malamis, D., Loizidou, M., 2014. An overview on desalination \& sustainability: renewable energy-driven desalination and brine ma nagement. Desalination And Water Treatment 57 (5), 2304-2314.

Xevg enos, D., Vidalis, A., Moustakas, K., Malamis, D., Loizidou, M., 2015. Sustainable management of brine effluent from desalination plants: the SOLBRINE system. Desalination and Water Treatment 53 (12), 3151-3160.

Xi, Y., Luo, Y., Luo, J., Luo, X., 2015. Removal of cadmium (II) from wastewater using novel cadmium ion-imprinted polymers. J. Chem. Eng. Data 60 (11), 3253-3261.

Xu, P., Ca th, T.Y., Robertson, A.P., Reinhard, M., Leckie, J.O., Drewes, J.E., 2013. Critical review of desalination concentrate management, treatment and beneficial use. Environ. Eng. Sci. 30 (8), 502-514.

Yacou, C., Smart, S., da Costa, J.C.D., 2015. Meso poro us TiO2 based membra nes for water desalination and brine processing. Separ. Purif. Technol. 147, $166-171$.

Yang, J., Luo, X., Yan, T., Lin, X., 2018. Recovery of cesium from saline lake brine with potassium cobalt hexa cyan of erra te-modified chrome-tanned leather scrap adsorbent. Colloid. Surface. Physicochem. Eng. Aspect. 537, 268-280.

Yang, Q.T., Xie, Q.L., Chen, N.C., Zhong, Y.J., 2018. Research progress on wastewater treatment by heavy metal ion imprinted polymer. Paper presented at the Materials Science Forum.

Yang, Y., Fein, J., 2017. Adsorption of metals by geomedia III: fundamentals and implications of metal adsorption. Elsevier.

Yan, Z., Yang, H., Qu, F., Yu, H., Liang, H., Li, G., Ma, J., 2017. Reverse osmosis brine treatment using direct contact membrane distillation: effects of feed temperature and velocity. Desalination 423, 149-156.

X. Ye Z. Wu W. Li H. Liu Q. Li B. Qing ... F. Ge Rubidium and cesium ion adsorption by an am monium molybdophosphate-calcium alginate composite adsorbent Colloid. Surface. Physicochem. Eng. Aspect. 342 1-3 20097683

Yi, Y., Tang, C., Yi, T., Yang, Z., Zhang, S., 2017. Heal th risk as sess ment of heavy metals in fish and accumulation patterns in food web in the upper Yangtze River, China. Ecotoxicol. Environ. Saf. 145, 295-302.

Yliheikkilä, K., Lappal ainen, K., Ca stro, P.M., Ibra him, K., Abu-Surrah, A., Lesk elä, M., Repo, T., 2006. Polymerization of acryla te monomers with MAO activated iron (II) and cobalt (II) complexes bearing tri-and tetradentate nitrogen ligands. Eur. Polym. J. 42 (1), 92-100.

Yuan, Z., Zhu, Y., Lan, Y., Chen, D., 2015. Preparation of Cu (II)-imprinted smart mi crogels for selective separation of copper ions. Separ. Sci. Technol. 50 (10), $1480-1486$.

Yu, X., Cui, J., Liu, C., Yuan, F., Gua, Y., Deng, T., 2020. Separation of magnesium from high $\mathrm{Mg} / \mathrm{Li}$ ratio by extraction with an organic system containing ionic liquid. Chem. Eng. Sci. 116019

L. Zhang L. Zhong S. Yang D. Liu Y. Wang S. Wang ... X. Zhang Adsorption of Ni (II) ion on Ni (II) ion-imprinted magnetic chitosan/poly (vinyl alcohol) composite Colloid Polym. Sci. 2939201524972506

Zhao, X., Feng, M., Jiao, Y., Zhang, Y., Wang, Y., Sha, Z., 2020. Lithium extraction from brine in an ionic selective desalination battery. Desalination 481, 114360.

Zhang, W., Xiong, R., Wei, G., 2009. Biological flocculation treatment on distillery wastewater and recirculation of wastewater. J. Ha zard Mater. 172 (2-3), 1252-1257.

Zoppas, F., Bernardes, A., Miró, E., Marchesini, F., 2018. Nitrate reduction of brines from water desalination plants employing a low metallic charge Pd, in 
catalyst and formic acid as reducing ag ent. Catal. Lett. 148 (8), 2572-2584.

Zhou, J., Chang, V.W.-C., Fane, A.G., 2011. Environmental life cycle as sess ment of brackish water reverse osmosis desalination for different electricity production models. Energy Environ. Sci. 4 (6), 2267-2278.

Zhou, J., Chang, V.W.-C., Fane, A.G., 2013. An improved life cycle impact as sess ment (LCIA) approach for as sess ing aquatic eco-toxic impact of brine disposal from seawater desalination plants. Desalination 308, 233-241.
Zouboulis, A.I., Peleka, E.N., Ntolia, A., 2019. Treatment of tannery wastewater with vibratory shear-enhanced processing membrane filtration. Separations 6 (2), 20.

Zwijnenberg, H., Koops, G., Wessling, M., 2005. Solar driven membra ne pervaporation for desalination processes. J. Membr. Sci. 250 (1-2), 235-246. 